\title{
Experimental phase and melting relations of metapelite in the upper mantle: implications for the petrogenesis of intraplate magmas
}

\author{
Carl Spandler • Greg Yaxley • David H. Green • \\ Dean Scott
}

Received: 15 September 2009/ Accepted: 27 January 2010/Published online: 24 February 2010

(C) Springer-Verlag 2010

\begin{abstract}
We performed a series of piston-cylinder experiments on a synthetic pelite starting material over a pressure and temperature range of 3.0-5.0 GPa and 1,100$1,600^{\circ} \mathrm{C}$, respectively, to examine the melting behaviour and phase relations of sedimentary rocks at upper mantle conditions. The anhydrous pelite solidus is between 1,150 and $1,200^{\circ} \mathrm{C}$ at $3.0 \mathrm{GPa}$ and close to $1,250^{\circ} \mathrm{C}$ at $5.0 \mathrm{GPa}$, whereas the liquidus is likely to be at $1,600^{\circ} \mathrm{C}$ or higher at all investigated pressures, giving a large melting interval of over $400^{\circ} \mathrm{C}$. The subsolidus paragenesis consists of quartz/ coesite, feldspar, garnet, kyanite, rutile, \pm clinopyroxene \pm apatite. Feldspar, rutile and apatite are rapidly melted out above the solidus, whereas garnet and kyanite are stable to high melt fractions ( $>70 \%)$. Clinopyroxene stability increases with increasing pressure, and quartz/coesite is the sole liquidus phase at all pressures. Feldspars are relatively Na-rich $[\mathrm{K} /(\mathrm{K}+\mathrm{Na})=0.4-0.5]$ at $3.0 \mathrm{GPa}$, but are nearly pure K-feldspar at $5.0 \mathrm{GPa}$. Clinopyroxenes are jadeite and Ca-eskolaite rich, with jadeite contents increasing with pressure. All supersolidus experiments produced alkaline dacitic melts with relatively constant $\mathrm{SiO}_{2}$ and $\mathrm{Al}_{2} \mathrm{O}_{3}$ contents. At $3.0 \mathrm{GPa}$, initial melting is
\end{abstract}

Communicated by J. Hoefs.

Electronic supplementary material The online version of this article (doi:10.1007/s00410-010-0494-2) contains supplementary material, which is available to authorized users.

C. Spandler $(\bowtie)$

School of Earth and Environmental Sciences,

James Cook University, Townsville, Australia

e-mail: carl.spandler@jcu.edu.au

G. Yaxley · D. H. Green · D. Scott

Research School of Earth Sciences, Australian National

University, Canberra, Australia controlled almost exclusively by feldspar and quartz, giving melts with $\mathrm{K}_{2} \mathrm{O} / \mathrm{Na}_{2} \mathrm{O} \sim 1$. At 4.0 and $5.0 \mathrm{GPa}$, lowfraction melting is controlled by jadeite-rich clinopyroxene and K-rich feldspar, which leads to compatible behaviour of $\mathrm{Na}$ and melts with $\mathrm{K}_{2} \mathrm{O} / \mathrm{Na}_{2} \mathrm{O} \gg 1$. Our results indicate that sedimentary protoliths entrained in upwelling heterogeneous mantle domains may undergo melting at greater depths than mafic lithologies to produce ultrapotassic dacitic melts. Such melts are expected to react with and metasomatise the surrounding peridotite, which may subsequently undergo melting at shallower levels to produce compositionally distinct magma types. This scenario may account for many of the distinctive geochemical characteristics of EM-type ocean island magma suites. Moreover, unmelted or partially melted sedimentary rocks in the mantle may contribute to some seismic discontinuities that have been observed beneath intraplate and island-arc volcanic regions.

Keywords Experimental petrology $\cdot$ Sediment melting · Mantle heterogeneity · Oceanic basalt · Crustal recycling

\section{Introduction}

The return of extensive volumes of crustal material to the mantle is an inevitable consequence of long-lived plate tectonics on Earth. Accordingly, previously subducted materials may collectively represent a significant proportion of the mantle (Plank and Langmuir 1998; Stracke et al. 2003), and may strongly influence its geochemical inventory and the production of mantle-derived magma (e.g., Hofmann 2003; Chauvel et al. 2008). Numerous experimental studies have shown that recycled mafic rocks may undergo extensive melting when present in upwelling 
upper mantle, and hence may contribute to the genesis of oceanic and intraplate magmatism (e.g., Yaxley 2000; Hirschmann et al. 2003; Pertermann and Hirschmann 2003; Kogiso and Hirschmann 2006; Spandler et al. 2008); a proposal that may reconcile many of the geochemical and isotopic features of these magma suites (Hofmann 2003; Hirschmann et al. 2003; Huang and Frey 2005; Sobolev et al. 2005, 2007; Herzberg 2006).

On the other hand, the ultimate fate of sedimentary material subducted into the mantle remains poorly understood. While components of some subducted sediment are recycled back to the crust via subduction-related magmatism (e.g., Plank and Langmuir 1998; Hermann and Spandler 2008), isotopic mass balance of subduction inputs and outputs indicates that much of this material avoids recycling at the subduction zone (Chauvel et al. 2009). There is compelling evidence from ultra-high pressure terranes (Becker and Altherr 1992; Chopin 2003; Shatsky and Sobolev 2003; Dobrzhinetskaya and Green 2007; Liu et al. 2007) and inclusions in diamonds (Eldridge et al. 1991; Daniels et al. 1996; Brenker et al. 2005) that sedimentary material is transported into, and stored in, the deep mantle. In particular, the preservation of large units of relatively undeformed and chemically unaltered metasediments in ultra-high pressure terranes, such as the Dora Maira (Chopin 2003; Schertl and Schreyer 2008) and Kokchetav (Shatsky and Sobolev 2003) Massifs indicates that, in at least some cases, there is little interaction between subducted sediments and external fluids or mantle rocks down to depths of $200 \mathrm{~km}$ or greater (Chopin 2003). We have little evidence on how sedimentary bodies behave at greater depths, but if these materials can survive diffusive re-equilibration (e.g., Kogiso et al. 2004) and mechanical mixing with surrounding mantle peridotite (a process which is currently poorly constrained; van Keken et al. 2002), distinct metasedimentary bodies may ultimately be included in peridotite-dominated heterogeneous upper mantle domains (Anderson 2006) or upwelling mantle plumes (Hofmann 2003). In either of these cases, sedimentary protoliths are likely to be involved in melting and magma-genesis processes in the upper mantle. This premise is supported by the unique isotopic and trace element characteristics of some MORB (Rehkämper and Hofmann 1997; Andres et al. 2002) and ocean-island basalt (OIB) suites (Weaver 1991; Eiler et al. 1997; Eisele et al. 2002; Huang and Frey 2005; Nielsen et al. 2006; Jackson et al. 2007; Chauvel et al. 2008; Class and le Roex 2008), which require sedimentary components to comprise part of their mantle sources. In particular, EM1 and EM2 type OIBs are expected to contain between 1 and $6 \mathrm{wt} \%$ sedimentary components, as calculated from isotope and trace element mixing models (Weaver 1991; Eiler et al. 1997; Eisele et al. 2002; Jackson et al. 2007; Class and le Roex
2008). These models usually assume bulk sediment mixing without consideration of potential geochemical fractionation caused by partial melting in the mantle. If follows therefore that knowledge of the melting behaviour of sedimentary materials in the upper mantle is crucial for understanding the evolution of many mantle-derived magma suites.

Subduction is considered to be the principle pathway for sedimentary rocks to enter the mantle, so it is not surprising that most previous experimental studies have examined phase relations and melting of these materials under hydrous conditions relevant to subduction-zones (e.g., Stern and Wyllie 1973; Nichols et al. 1994; Hermann and Green 2001; Schmidt et al. 2004; Hermann and Spandler 2008). Nevertheless, experimental results show that sedimentary rocks may evolve to anhydrous or nearly-anhydrous compositions once subducted to depths greater than 250-300 km (e.g., Ono 1998). Only a few experimental studies have investigated these conditions specifically (Irifune et al. 1994; Dobrzhinetskaya and Green 2007; Rapp et al. 2008; Wu et al. 2009), and most of the focus of these studies has been on the relatively high pressure range of 6-24 GPa. There have been no studies to determine the anhydrous phase relations and melting of sedimentary compositions under mantle conditions at pressures of less than $6 \mathrm{GPa}$. In this paper, we present results of pistoncylinder experiments on an anhydrous pelite starting material from 3.0 to $5.0 \mathrm{GPa}$ and between 1,100 and $1,600^{\circ} \mathrm{C}$ (Table 1$)$. We outline phase relations, melting conditions and melt compositions of this material over the entire investigated pressure-temperature range. The experiments were carried out at conditions relevant to upwelling asthenospheric mantle, so the results of this work will help to constrain the fate of subducted, dehydrated sediments recycled into the convecting upper mantle and also contribute directly to our understanding of the melting of mantle heterogeneities and the genesis of oceanisland magma suites.

\section{Experimental approach and analytical techniques}

The starting material used for all experiments (EPSM) was synthesised using the sol-gel method, as described in detail in Spandler et al. (2007). It is a homogenous anhydrous glass of pelitic composition (Table 2) that is representative of terrigenous sediments currently being subducted at plate margins (Plank and Langmuir 1998; Spandler et al. 2007; Hermann and Spandler 2008). During preparation, Fe was added to the glass as pure synthetic fayalite, meaning the starting material is relatively reduced in nature.

The experimental and analytical techniques employed in this study are very similar to those outlined in Spandler 
Table 1 Details of the experimental run conditions and phase proportions of run products

\begin{tabular}{|c|c|c|c|c|c|c|}
\hline $\begin{array}{l}\text { Run } \\
\text { no. }\end{array}$ & $\begin{array}{l}\text { Pressure } \\
(\mathrm{GPa})\end{array}$ & $\begin{array}{l}\text { Nominal } \\
\text { temperature }\left({ }^{\circ} \mathrm{C}\right)\end{array}$ & $\begin{array}{l}\text { Duration } \\
\text { (h) }\end{array}$ & $\begin{array}{l}\text { Calculated } \\
\text { temperature }\left({ }^{\circ} \mathrm{C}\right)\end{array}$ & Phase proportions & $\sum r^{2}$ \\
\hline EP1 & 3.0 & 1,100 & 142 & $1,087 \pm 45$ & $\begin{array}{l}\text { qtz [31], gt [17.5], kspr [33], cpx [14], ky [4.5], } \\
\text { rt [0.5], ap [tr] }\end{array}$ & 0.005 \\
\hline EP2 & 3.0 & 1,150 & 147 & - & qtz [29], gt [24], kspr [45], ky [1], rt [0.5], ap [tr] & 0.003 \\
\hline EP15 & 3.0 & 1,200 & 123 & - & qtz [29], gt [24], kspr [41], ky [1], rt [0.35], melt [4] & 0.057 \\
\hline EP10 & 3.0 & 1,230 & 141 & - & qtz [25.5], gt [21], kspr [24], ky [1], melt [28] & 0.028 \\
\hline EP3 & 3.0 & 1,260 & 138 & - & qtz [20.5], gt [16.5], ky [1], melt [62] & 0.039 \\
\hline EP4 & 3.0 & 1,300 & 75 & - & qtz [18], gt [13], ky [tr], melt [69] & 0.044 \\
\hline EP8 & 3.0 & 1,350 & 30 & - & qtz [15.5], gt [7.5], melt [77] & 0.014 \\
\hline EP7 & 3.0 & 1,400 & 24 & - & qtz [10.5], melt [89] & 0.009 \\
\hline EP25 & 3.0 & 1,460 & 10 & - & qtz [9], melt [91] & 0.100 \\
\hline EP26 & 3.0 & 1,500 & 10 & - & qtz [4.5], melt [95.5] & 0.010 \\
\hline EP28 & 3.0 & 1,600 & 10 & - & melt $[100]$ & - \\
\hline EP22 & 4.0 & 1,220 & 140 & $1,229 \pm 23$ & $\begin{array}{l}\text { coe [33], gt [13], kspr [20], cpx [28], ky [5], rt [0.2], } \\
\text { melt [tr] }\end{array}$ & 0.038 \\
\hline EP12 & 4.0 & 1,250 & 100 & $1,280 \pm 28$ & $\begin{array}{l}\text { coe [28.5], gt [13.5], kspr [8], cpx [24], ky [4], rt [0.1], } \\
\text { melt [22] }\end{array}$ & 0.028 \\
\hline EP11 & 4.0 & 1,300 & 72 & $1,318 \pm 32$ & coe [25.5], gt [14], cpx [13], ky [4.5], melt [43.5] & 0.016 \\
\hline EP13 & 4.0 & 1,350 & 48 & - & coe [19], gt [11.5], ky [3], melt [66.5] & 0.020 \\
\hline EP14 & 4.0 & 1,400 & 24 & - & coe [14], gt [7], ky [1], melt [78] & 0.019 \\
\hline EP23 & 4.0 & 1,450 & 10 & - & coe [8.5], gt [1.5], melt [90] & 0.040 \\
\hline EP27 & 4.0 & 1,550 & 10 & - & coe [6], melt [94] & $0.022^{\mathrm{a}}$ \\
\hline EP16 & 5.0 & 1,250 & 120 & $1,252 \pm 26$ & coe [33], gt [14], kspr [19.5], cpx [29], ky [5], rt [0.3] & 0.067 \\
\hline EP20 & 5.0 & 1,280 & 96 & $1,305 \pm 25$ & $\begin{array}{l}\text { coe [31.5], gt [14], kspr [14.5], cpx [29], ky [5], } \\
\text { rt [0.3], melt [6] }\end{array}$ & 0.056 \\
\hline EP21 & 5.0 & 1,320 & 72 & $1,342 \pm 23$ & coe [28.5], gt [13], cpx [23], ky [5], melt [30.5] & 0.011 \\
\hline EP17 & 5.0 & 1,400 & 24 & $1,424 \pm 22$ & coe [27], gt [11], cpx [16], ky [5], melt [41] & 0.016 \\
\hline EP19 & 5.0 & 1,450 & 12 & - & coe [19.5], gt [10], ky [2.5], melt [68.5] & 0.014 \\
\hline EP24 & 5.0 & 1,500 & 10 & - & coe [12], gt [1.5], melt [86.5] & 0.030 \\
\hline EP29 & 5.0 & 1,600 & 10 & - & coe [3.5], melt [96.5] & $0.036^{\mathrm{a}}$ \\
\hline
\end{tabular}

Calculated temperatures were calculated from compositions of coexisting gt and cpx using the thermometric equations of Ellis and Green (1979). Mineral proportions were calculated by least-squares regressions using average phase compositions and were cross-checked with petrographically estimated mineral proportions. Note the exceptionally low sum of squares of the residual $\left(\sum r^{2}\right)$, indicating an excellent regression of the mineral proportions

$q t z$ quartz, gt garnet, $k s p r$ feldspar, cpx clinopyroxene, $k y$ kyanite, $r t$ rutile, ap apatite, coe coesite

${ }^{a}$ Runs EP27 and EP29 suffered Fe loss to the Pt capsule, so the melt compositions in these experiments were adjusted by 1.2 and 0.56 wt $\%$ FeO, respectively, based on mass balance constraints

et al. (2008), and so are only briefly described here. All experiments were conducted at the Research School of Earth Sciences, Australian National University (ANU) using $200 \mathrm{~T}$ Boyd-England type piston-cylinder presses for experiments at 3.0 and $4.0 \mathrm{GPa}$, and a $500 \mathrm{~T}$, ultra-highpressure piston-cylinder apparatus for experiments at $5.0 \mathrm{GPa}$. 20-30 mg of EPSM sample loaded into graphite capsules were subsequently placed into $3.5-\mathrm{mm}$ Pt capsules (open at one end) and heated to $200^{\circ} \mathrm{C}$ in an oven for $\sim 10 \mathrm{~h}$ to remove any absorbed water. After removal from the oven, the capsules were immediately welded closed. The use of the internal graphite capsule is likely to have fixed experimental oxygen fugacity at or below the $\mathrm{CCO}$ buffer; conditions at which we expect there to be little change in the redox state of the starting material during the experiments. Therefore, we are confident that all experiments were conducted under anhydrous or very near to anhydrous conditions. All experiments used standard 12.7-mm salt-Pyrex assemblies with graphite heaters and $\mathrm{MgO}$ spacers above and below the capsules. Temperature was controlled using type-B thermocouples $\left(\mathrm{Pt}_{94} \mathrm{Rh}_{6} /\right.$ $\mathrm{Pt}_{70} \mathrm{Rh}_{30}$ ) and a Eurotherm temperature controller and is precise to within $3^{\circ} \mathrm{C}$. Temperature gradients across the sample are expected to be less than $10^{\circ} \mathrm{C}$. Due to the high 
Table 2 Composition of pelitic starting material (EPSM) and experimental melts

\begin{tabular}{|c|c|c|c|c|c|c|c|c|c|c|c|}
\hline $\begin{array}{l}\text { Label/run } \\
\text { Pressure }(\mathrm{GPa}) \\
\text { Temperature }\left({ }^{\circ} \mathrm{C}\right) \\
\text { Analyses } \\
\text { Percentage of melt }\end{array}$ & EPSM & $\begin{array}{l}\text { EP15 } \\
3.0 \\
1,200 \\
7 \\
4\end{array}$ & SD & $\begin{array}{l}\text { EP10 } \\
3.0 \\
1,230 \\
10 \\
28\end{array}$ & SD & $\begin{array}{l}\text { EP3 } \\
3.0 \\
1,260 \\
11 \\
62\end{array}$ & SD & $\begin{array}{l}\text { EP4 } \\
3.0 \\
1,300 \\
9 \\
69\end{array}$ & SD & $\begin{array}{l}\text { EP8 } \\
3.0 \\
1,350 \\
10 \\
77\end{array}$ & SD \\
\hline $\mathrm{SiO}_{2}$ & 69.02 & 67.29 & 0.37 & 67.15 & 0.34 & 66.94 & 0.18 & 66.20 & 0.13 & 65.62 & 0.24 \\
\hline $\mathrm{TiO}_{2}$ & 0.67 & 1.44 & 0.11 & 1.48 & 0.12 & 0.85 & 0.08 & 0.86 & 0.11 & 0.79 & 0.07 \\
\hline $\mathrm{Al}_{2} \mathrm{O}_{3}$ & 14.74 & 16.63 & 0.37 & 16.44 & 0.24 & 16.86 & 0.10 & 16.89 & 0.09 & 16.84 & 0.15 \\
\hline $\mathrm{FeO}$ & 4.68 & 1.90 & 0.09 & 2.18 & 0.12 & 2.62 & 0.10 & 3.42 & 0.10 & 4.43 & 0.11 \\
\hline $\mathrm{MgO}$ & 2.52 & 0.60 & 0.08 & 0.73 & 0.06 & 0.91 & 0.04 & 1.28 & 0.05 & 1.82 & 0.04 \\
\hline $\mathrm{CaO}$ & 2.46 & 2.01 & 0.07 & 2.20 & 0.12 & 2.55 & 0.08 & 2.86 & 0.05 & 2.89 & 0.07 \\
\hline $\mathrm{Na}_{2} \mathrm{O}$ & 2.62 & 3.96 & 0.15 & 3.98 & 0.11 & 4.06 & 0.06 & 3.69 & 0.06 & 3.34 & 0.07 \\
\hline $\mathrm{K}_{2} \mathrm{O}$ & 2.95 & 5.43 & 0.12 & 5.18 & 0.10 & 4.91 & 0.07 & 4.47 & 0.08 & 3.93 & 0.04 \\
\hline $\mathrm{P}_{2} \mathrm{O}_{5}$ & 0.32 & 0.73 & 0.09 & 0.66 & 0.05 & 0.30 & 0.08 & 0.33 & 0.06 & 0.34 & 0.09 \\
\hline $\begin{array}{l}\text { Label/run } \\
\text { Pressure }(\mathrm{GPa}) \\
\text { Temperature }\left({ }^{\circ} \mathrm{C}\right) \\
\text { Analyses } \\
\text { Percentage of melt }\end{array}$ & $\begin{array}{l}\text { EP13 } \\
4.0 \\
1,350 \\
10 \\
66.5\end{array}$ & SD & $\begin{array}{l}\text { EP14 } \\
4.0 \\
1,400 \\
8 \\
78\end{array}$ & SD & $\begin{array}{l}\mathrm{EP} 23 \\
4.0 \\
1,450 \\
10 \\
90\end{array}$ & SD & $\begin{array}{l}\text { EP27 } \\
4.0 \\
1,550 \\
10 \\
94\end{array}$ & SD & $\begin{array}{l}\text { EP21 } \\
5.0 \\
1,320 \\
6 \\
30.5\end{array}$ & SD & \\
\hline $\mathrm{SiO}_{2}$ & 66.38 & 0.15 & 66.20 & 0.13 & 66.72 & 0.18 & 67.02 & 0.17 & 67.30 & 0.74 & \\
\hline $\mathrm{TiO}_{2}$ & 0.89 & 0.08 & 0.83 & 0.10 & 0.73 & 0.02 & 0.74 & 0.02 & 1.25 & 0.13 & \\
\hline $\mathrm{Al}_{2} \mathrm{O}_{3}$ & 16.08 & 0.09 & 16.17 & 0.10 & 15.98 & 0.13 & 15.72 & 0.15 & 15.11 & 0.40 & \\
\hline $\mathrm{FeO}$ & 3.85 & 0.16 & 4.48 & 0.14 & 4.78 & 0.15 & 4.99 & 0.15 & 2.34 & 0.14 & \\
\hline $\mathrm{MgO}$ & 1.39 & 0.05 & 2.01 & 0.05 & 2.68 & 0.04 & 2.61 & 0.03 & 0.52 & 0.09 & \\
\hline $\mathrm{CaO}$ & 2.84 & 0.06 & 2.91 & 0.08 & 2.67 & 0.03 & 2.62 & 0.06 & 1.01 & 0.04 & \\
\hline $\mathrm{Na}_{2} \mathrm{O}$ & 3.73 & 0.04 & 3.28 & 0.08 & 2.85 & 0.04 & 2.73 & 0.03 & 2.42 & 0.20 & \\
\hline $\mathrm{K}_{2} \mathrm{O}$ & 4.43 & 0.08 & 3.78 & 0.06 & 3.34 & 0.10 & 3.27 & 0.03 & 9.37 & 0.24 & \\
\hline $\mathrm{P}_{2} \mathrm{O} 5$ & 0.41 & 0.06 & 0.35 & 0.07 & 0.24 & 0.04 & 0.30 & 0.02 & 0.68 & 0.13 & \\
\hline $\begin{array}{l}\text { Label/run } \\
\text { Pressure }(\mathrm{GPa}) \\
\text { Temperature }\left({ }^{\circ} \mathrm{C}\right) \\
\text { Analyses } \\
\text { Percentage of melt }\end{array}$ & $\begin{array}{l}\text { EP7 } \\
3.0 \\
1,400 \\
7 \\
89 \\
\end{array}$ & SD & $\begin{array}{l}\mathrm{EP} 25 \\
3.0 \\
1,460 \\
7 \\
91 \\
\end{array}$ & SD & $\begin{array}{l}\mathrm{EP} 26 \\
3.0 \\
1,500 \\
10 \\
95.5 \\
\end{array}$ & SD & $\begin{array}{l}\text { EP12 } \\
4.0 \\
1,250 \\
6 \\
22 \\
\end{array}$ & SD & $\begin{array}{l}\text { EP11 } \\
4.0 \\
1,300 \\
5 \\
43.5 \\
\end{array}$ & SD & \\
\hline $\mathrm{SiO}_{2}$ & 65.45 & 0.26 & 65.99 & 0.59 & 67.61 & 0.24 & 67.66 & 0.43 & 67.18 & 0.32 & \\
\hline $\mathrm{TiO}_{2}$ & 0.71 & 0.09 & 0.77 & 0.04 & 0.68 & 0.06 & 1.26 & 0.05 & 0.97 & 0.08 & \\
\hline $\mathrm{Al}_{2} \mathrm{O}_{3}$ & 16.54 & 0.12 & 16.52 & 0.33 & 15.45 & 0.10 & 15.91 & 0.29 & 15.91 & 0.14 & \\
\hline $\mathrm{FeO}$ & 5.16 & 0.21 & 4.94 & 0.13 & 4.91 & 0.16 & 2.09 & 0.06 & 2.61 & 0.13 & \\
\hline $\mathrm{MgO}$ & 2.81 & 0.04 & 2.76 & 0.06 & 2.60 & 0.03 & 0.50 & 0.04 & 0.71 & 0.08 & \\
\hline $\mathrm{CaO}$ & 2.77 & 0.07 & 2.84 & 0.08 & 2.59 & 0.06 & 1.12 & 0.05 & 1.64 & 0.08 & \\
\hline $\mathrm{Na}_{2} \mathrm{O}$ & 2.92 & 0.03 & 2.76 & 0.07 & 2.70 & 0.06 & 2.72 & 0.13 & 3.85 & 0.09 & \\
\hline $\mathrm{K}_{2} \mathrm{O}$ & 3.33 & 0.11 & 3.42 & 0.10 & 3.16 & 0.05 & 7.97 & 0.27 & 6.69 & 0.12 & \\
\hline $\mathrm{P}_{2} \mathrm{O}_{5}$ & 0.32 & 0.08 & nd & - & 0.28 & 0.02 & 0.77 & 0.10 & 0.44 & 0.10 & \\
\hline $\begin{array}{l}\text { Label/run } \\
\text { Pressure }(\mathrm{GPa}) \\
\text { Temperature }\left({ }^{\circ} \mathrm{C}\right) \\
\text { Analyses } \\
\text { Percentage of melt }\end{array}$ & $\begin{array}{l}\text { EP17 } \\
5.0 \\
1,400 \\
8 \\
41\end{array}$ & SD & $\begin{array}{l}\text { EP19 } \\
5.0 \\
1,450 \\
9 \\
68.5\end{array}$ & SD & $\begin{array}{l}\text { EP24 } \\
5.0 \\
1,500 \\
12 \\
86.5\end{array}$ & $\mathrm{SD}$ & $\begin{array}{l}1, \\
1 \\
9\end{array}$ & 29 & SD & & \\
\hline $\mathrm{SiO}_{2}$ & 65.24 & 0.26 & 65.06 & 0.21 & 65.11 & 0.30 & & .04 & 0.25 & & \\
\hline $\mathrm{TiO}_{2}$ & 1.08 & 0.09 & 0.92 & 0.08 & 0.72 & 0.02 & & 68 & 0.02 & & \\
\hline $\mathrm{Al}_{2} \mathrm{O} 3$ & 15.85 & 0.15 & 16.44 & 0.10 & 16.65 & 0.08 & & 30 & 0.14 & & \\
\hline
\end{tabular}


Table 2 continued

\begin{tabular}{lllllllll}
\hline Label/run & EP17 & SD & EP19 & SD & EP24 & SD & EP29 & SD \\
Pressure $(\mathrm{GPa})$ & 5.0 & & 5.0 & & 5.0 & & 5.0 & 1,600 \\
Temperature $\left({ }^{\circ} \mathrm{C}\right)$ & 1,400 & & 1,450 & & 1,500 & & 12 & \\
Analyses & 8 & & 9 & & & 15 & \\
Percentage of melt & 41 & & 68.5 & & 86.5 & & 97 & \\
\hline $\mathrm{FeO}$ & 3.65 & 0.06 & 4.32 & 0.20 & 5.06 & 0.14 & 4.86 & 0.10 \\
$\mathrm{MgO}$ & 1.10 & 0.08 & 1.80 & 0.05 & 2.80 & 0.04 & 2.53 & 0.06 \\
$\mathrm{CaO}$ & 2.17 & 0.11 & 3.01 & 0.09 & 2.82 & 0.03 & 2.53 & 0.08 \\
$\mathrm{Na} 2 \mathrm{O}$ & 3.48 & 0.06 & 3.78 & 0.06 & 3.06 & 0.08 & 2.61 & 0.05 \\
$\mathrm{~K}_{2} \mathrm{O}$ & 6.98 & 0.11 & 4.31 & 0.07 & 3.51 & 0.14 & 3.19 & 0.04 \\
$\mathrm{P}_{2} \mathrm{O} 5$ & 0.45 & 0.10 & 0.37 & 0.08 & 0.27 & 0.04 & 0.27 & 0.02
\end{tabular}

All compositions are normalised to $100 \%$. Analytical totals were between 96.5 and $100.2 \mathrm{wt} \%$. Low totals (96.5-99\%) were found for lowdegree melts that are expected to contain significant trace element contents, as the starting material contains $\sim 0.5 \mathrm{wt} \%$ of incompatible trace elements (see Spandler et al. 2007). MnO was below detection limits $(<0.2 \mathrm{wt} \%)$ in all melt analyses. The 'analyses' row refers to the number of analyses used to calculate the average

$S D$ standard deviation; $n d$ no data

run temperatures, low friction assemblies and long experimental run durations ( $\geq 10 \mathrm{~h}$; Table 1) no friction corrections were applied to the pressure measurements, which are considered to be accurate to $\pm 0.1 \mathrm{GPa}$. Experiments were terminated by turning off power to the apparatus, resulting in quenching to below $200^{\circ} \mathrm{C}$ in less than $10 \mathrm{~s}$. Details of the experimental run conditions and resulting phase proportions are presented in Table 1.

Backscattered electron imaging of the experimental run products was conducted using a JEOL 6400 scanning electron microscope (SEM), housed at the Electron Microscopy Unit, ANU, and a Zeiss EVO50 SEM, at the Institute of Geological Sciences, University of Bern. Beam currents and acceleration voltages were, respectively, set to $1.0 \mathrm{nA}$ and $15 \mathrm{kV}$ for the JEOL 6400, and 0.5-1.0 nA and $20 \mathrm{kV}$ for the Zeiss EVO50. Examples of the backscattered images produced by the Zeiss EVO50 are presented in Fig. 1.

Mineral grains and quenched melt (glass) pools from the experiments were analysed for major elements using a Link EDS detector mounted to the JEOL 6400 SEM, with a counting time of $100 \mathrm{~s}$. For all mineral analyses a focussed beam was used, and care was taken to avoid mineral inclusions or quench overgrowth on grain rims. For the glass analyses a defocused beam of $>25 \mu \mathrm{m}^{2}$ was used in all experiments containing sufficiently large glass pools (all experiments with $>20 \%$ melting). In experiments with lower melt fractions (EP15, EP20 and EP22) the glass pools were too small $\left(<10 \mu \mathrm{m}^{2}\right)$ to use the defocused beam, so glass in EP15 was analysed using a focussed beam $\left(\sim 1 \mu \mathrm{m}^{2}\right)$. For these analyses, $\mathrm{Na}$ and $\mathrm{K}$ concentrations were continually monitored during acquisition, and it was found that both elements recorded relatively constant count rates over the analysis time, indicating that $\mathrm{Na}$ and $\mathrm{K}$ loss during analysis was negligible. Glass pools in EP20 and EP22 were too small for accurate quantitative analysis. Previous studies show that this EDS technique provides mineral compositional data that are comparable in accuracy to analyses conducted by WDS on an electron microprobe (e.g., Hermann et al. 2005; Spandler et al. 2008). Nonetheless, as a cross-check on the accuracy of the EDS results, feldspar, clinopyroxene and garnet in number of representative experiments were also analysed by WDS using a JEOL JXA8200 superprobe at the Advanced Analytical Centre, James Cook University, Townsville, Australia, with acceleration voltage, beam current and beam diameter were set to $15 \mathrm{kV}, 20 \mathrm{nA}$ and $1 \mu \mathrm{m}$, respectively. Elements determined by EDS and WDS are within error of each other in almost all cases (see Supplementary Item 1), which demonstrates that the two techniques are compatible and that our EDS results are accurate.

All experimental products were carefully scrutinised to evaluate attainment of equilibrium. Within error, no systematic variations in mineral or melt compositions were found across the width or length of the experimental charges, although two experiments conducted below the solidus (EP1 and EP16) contained some garnets grains with cores slightly higher in Ti than the rims. These garnet cores are interpreted to represent garnet growth before complete equilibrium was reached, and so we only consider the garnet rims as part of the equilibrium mineral assemblages. Mineral zoning (exclusive of quenching effects) was not found in any other minerals. Two high temperature experiments (EP27 and EP29) contained melt veins through the graphite capsules, which allowed some Fe loss from the melt to the Pt capsule. In both cases the amount of Fe loss was $<25 \%$, and the melt compositions could be 
Fig. 1 Backscattered-electron images of experimental run products. a Subsolidus run EP1 $\left(3.0 \mathrm{GPa}, 1,100^{\circ} \mathrm{C}\right)$ containing fine-grained garnet (gt), clinopyroxene (cpx), quartz (qtz), feldspar (kspr), kyanite (ky) and accessory rutile (rt) and apatite (ap). b Run EP10 $\left(3.0 \mathrm{GPa}, 1,230^{\circ} \mathrm{C}\right)$ containing gt, qtz, kspr, ky and melt. c Run EP8 (3.0 GPa, $\left.1,350^{\circ} \mathrm{C}\right)$ containing gt, qtz and a high degree of melt. d Run EP12 $\left(4.0 \mathrm{GPa}, 1,250^{\circ} \mathrm{C}\right)$ containing gt, kspr, cpx, coesite (coe), ky and melt. e Run EP13 (4.0 GPa, $1,350^{\circ} \mathrm{C}$ ) containing gt, coe, ky and a high degree of melt. f Run $\mathrm{EP} 17\left(5.0 \mathrm{GPa}, 1,400^{\circ} \mathrm{C}\right)$ containing gt, cpx, coe, ky and melt. Note the globular form of qtz in the $3.0 \mathrm{GPa}$ experiments compared to the tabular or needle-like crystals of coe formed in experiments at 4.0 and $5.0 \mathrm{GPa}$
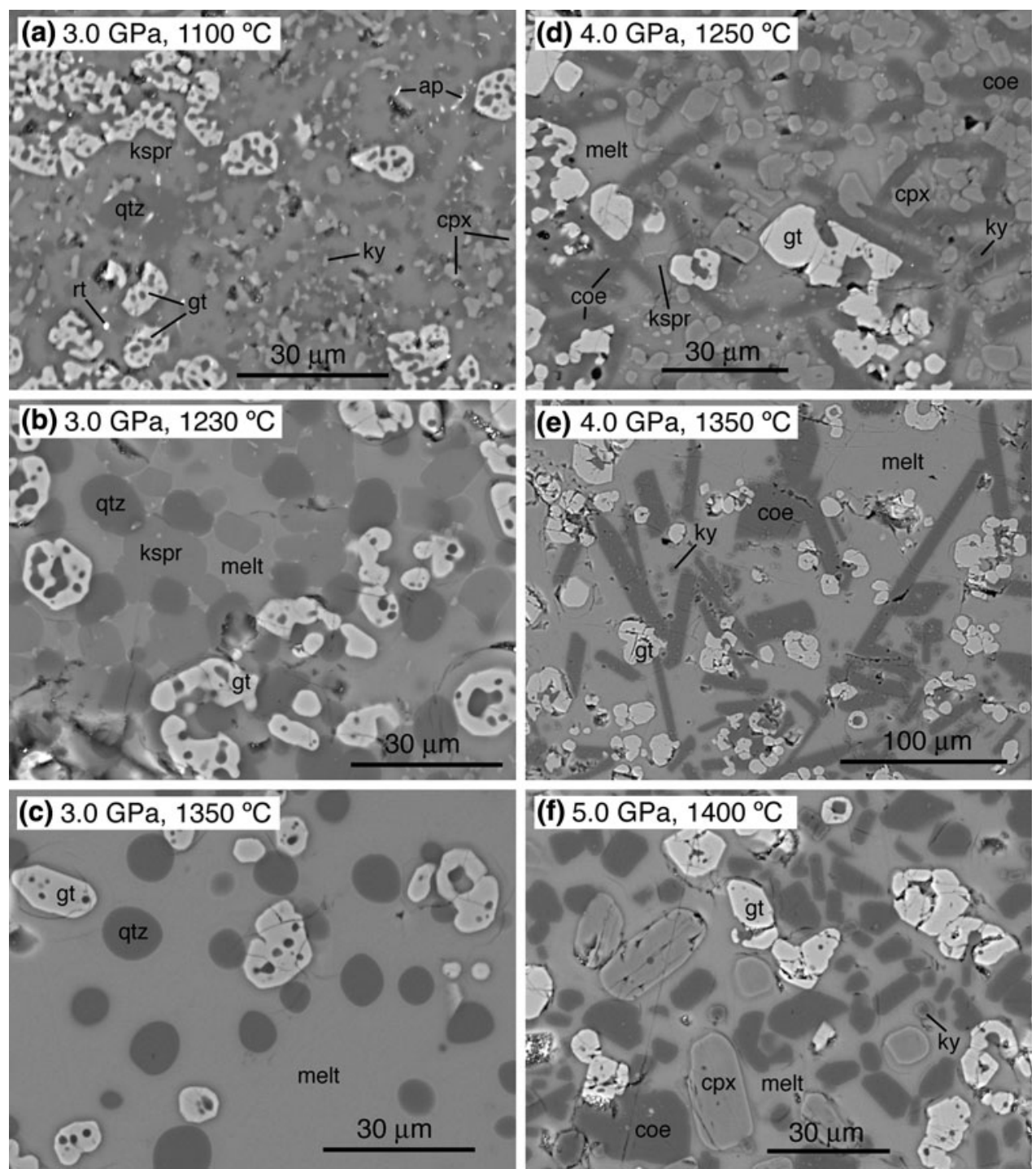

corrected for $\mathrm{Fe}$ loss using mass balance calculations (Table 2). Where possible, temperatures were calculated from coexisting garnet-clinopyroxene pairs using the geothermometer of Ellis and Green (1979). The calculated temperatures are within $30^{\circ} \mathrm{C}$ of the nominal run temperature for all experiments (Table 1). This result indicates that the thermocouple temperature readings closely correspond to the temperatures within the capsules during the runs.

\section{Results}

Phase relations

Complete phase assemblages were determined for all experiments (Table 1), including the subsolidus runs with small grain-sizes $(<10 \mu \mathrm{m})$. Phase proportions were determined using average phase compositions and leastsquares regressions, and in all cases the results are consistent with petrographic observations. The least-squares calculations are particularly precise $\left(\Sigma r^{2}<0.1\right)$, due to the strong partitioning of many of the elements into specific phases (e.g., Ti into rutile; $\mathrm{K}$ into feldspar).

\section{$3.0 \mathrm{GPa}$}

In experiments at $3.0 \mathrm{GPa}$ run products generally have globular, equigranular mineral textures with garnet commonly preserving abundant melt and quartz inclusions (Fig. 1a-c). Experiments at 1,100 and $1,150^{\circ} \mathrm{C}$ produced subsolidus mineral assemblages dominated by quartz, feldspar and garnet, although accessory kyanite, apatite and rutile are also present as micrometre-sized needles (Fig. 1a). At 3.0 GPa clinopyroxene is also present as a major phase at $1,100^{\circ} \mathrm{C}$, but is absent in higher temperature 
Fig. 2 Experimentally determined phase relations for EPSM. Open circles represent subsolidus experiments. Filled circles represent experiments containing melt. The figure has been gradationally shaded to show the increase in melt fraction with temperature and pressure. The location of the quartz-coesite transition is from Bose and Ganguly (1995)

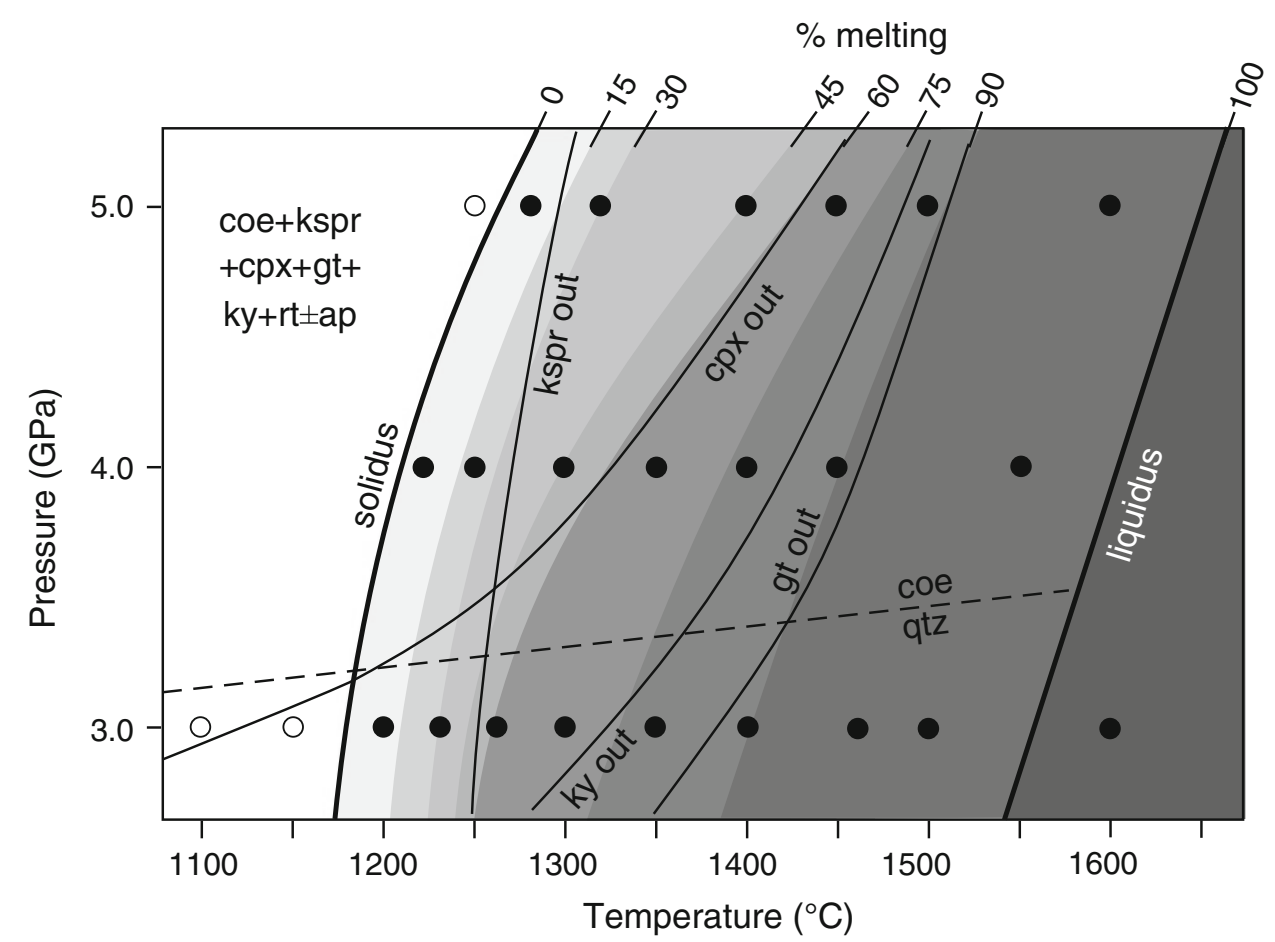

runs. Melt is present in all runs above $1,200^{\circ} \mathrm{C}$ (Fig. 1b, c), which constrains the $3.0 \mathrm{GPa}$ solidus to between 1,150 and $1,200^{\circ} \mathrm{C}$ (Fig. 2). Above the solidus, apatite and rutile are very quickly dissolved into the melt, but it is the dissolution of feldspar that primarily controls melt productivity (i.e., the change in percentage of melt as a function of temperature). Rapid melting out of feldspar results in melt proportions of over $50 \%$ within $100^{\circ} \mathrm{C}$ of the solidus (Fig. 2).

At higher temperatures at $3.0 \mathrm{GPa}$, melt productivity decreases as kyanite, followed by garnet are progressively melted out, leaving quartz as the sole liquidus phase by $1,400^{\circ} \mathrm{C}$ at melt fractions in excess of $80 \%$. Quartz remains a residual phase to over $1,500^{\circ} \mathrm{C}$, whereas at $1,600^{\circ} \mathrm{C}$ only melt is found.

\section{0 and $5.0 \mathrm{GPa}$}

Unlike the blebby quartz in the experiments at $3.0 \mathrm{GPa}$ (Fig. $1 \mathrm{a}-\mathrm{c}$ ), the $\mathrm{SiO}_{2}$ phase in the 4.0- and 5.0-GPa experiments occurs as tabular or bladed crystals that can reach up to $0.5 \mathrm{~mm}$ in length (Fig. 1d-f). This textural difference is consistent with the expected presence of coesite in the higher pressure experiments, as the quartz-coesite transition is likely to be between 3.0 and $4.0 \mathrm{GPa}$ at our run temperatures (Bose and Ganguly 1995). The subsolidus mineral assemblage at $5.0 \mathrm{GPa}$ (run EP16; Table 1) is similar to the subsolidus assemblage at $3.0 \mathrm{GPa}, 1,100^{\circ} \mathrm{C}$, although apatite was not recognised at 5.0 GPa. The solidus at 4.0 and $5.0 \mathrm{GPa}$ is located at close to $1,220^{\circ} \mathrm{C}$, and between 1,250 and $1,280^{\circ} \mathrm{C}$, respectively (Fig. 2). Clinopyroxene, feldspar, garnet, coesite and minor kyanite occur above the solidus at 4.0 and $5.0 \mathrm{GPa}$, although feldspar is melted out more rapidly with increasing pressure. In contrast, the stability field of clinopyroxene tends to expand with pressure, with clinopyroxene persisting as a residual phase even with melt fractions of over $50 \%$ at 4.0 and $5.0 \mathrm{GPa}$. Kyanite is also more abundant at these pressures than at 3.0 $\mathrm{GPa}$. Melt productivity tends to become more constant through the melting interval at higher pressures (Fig. 2). With increasing temperature above the solidus, feldspar is the first phase to be melted out, followed by clinopyroxene. Garnet and kyanite are exhausted at around 80-90\% melting, which leaves coesite as the sole liquidus phase. At 4.0 and 5.0 $\mathrm{GPa}$, coesite remains a residual phase to over 1,550 and $1,600^{\circ} \mathrm{C}$, respectively. For all pressure conditions, the total melting interval is around $400^{\circ} \mathrm{C}$ with quartz/coesite the only mineral phase present for 150 $200^{\circ} \mathrm{C}$ below the liquidus.

Phase compositions

\section{Feldspar}

We observe only a single alkali feldspar in our experiments, consistent with the high temperature $\left(1,100^{\circ} \mathrm{C}\right)$ subsolidus phase relations of an adamellite composition investigated by Green and Lambert (1965). Feldspar in our 3.0-GPa experiments lacking clinopyroxene (EP2, EP15 and EP10) is Na-rich $(\mathrm{K} /(\mathrm{K}+\mathrm{Na})=0.42-0.44$; Fig. 3) 


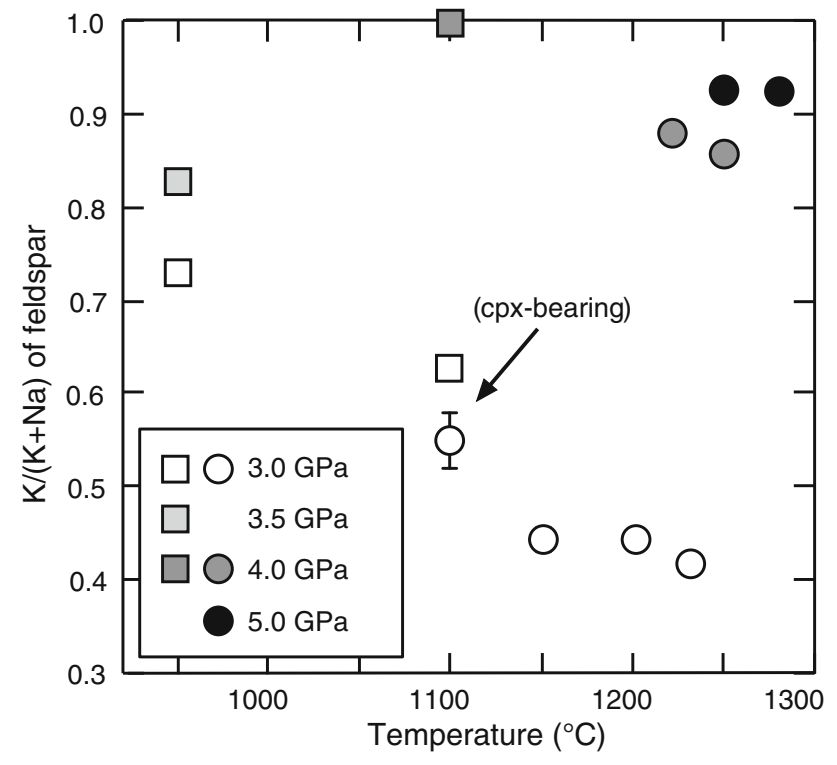

Fig. 3 Atomic $\mathrm{K} /(\mathrm{K}+\mathrm{Na})$ of experimental feldspars as a function of pressure and temperature. Round symbols are data from this study and the square symbols are data from Green and Lambert (1965). Error bars represent $1 \mathrm{SD}$ of multiple mineral analyses. In most cases, the error bars are smaller than the plotted symbols with $\mathrm{CaO}$ contents between 1.5 and 2.0 wt\% (Table 3). The lowest temperature experiment EP1 (3.0 GPa, $1,100^{\circ} \mathrm{C}$ ) also contains Na-rich feldspar, albeit with higher $\mathrm{K} /(\mathrm{K}+\mathrm{Na})$ of $\sim 0.55$ and lower $\mathrm{CaO}$ contents $(\sim 0.7$ $\mathrm{wt} \%)$ due to the presence of jadeite-rich clinopyroxene. K/ $(\mathrm{K}+\mathrm{Na})$ of feldspar increases markedly with increasing pressure (Fig. 3). Feldspars at 4.0 and 5.0 GPa have low $\mathrm{CaO}(<0.2 \mathrm{wt} \%)$ and $\mathrm{Na}_{2} \mathrm{O}(<1.6 \mathrm{wt} \%)$ contents, and, hence, approach end-member $\mathrm{K}$-feldspar in composition $(\mathrm{K} /(\mathrm{K}+\mathrm{Na})=0.85-0.92)$.

\section{Clinopyroxene}

Clinopyroxene end-member components were calculated following the methods of Pertermann and Hirschmann (2003). Experimental clinopyroxenes are jadeite-rich with significant enstatite-ferrosilite and diopside-hedenbergite components (Fig. 4; Table 4). $\mathrm{Al}_{2} \mathrm{O}_{3}$ contents are between 17.6 and $20.5 \mathrm{wt} \%$, which is significantly higher than clinopyroxenes from anhydrous mafic eclogite compositions (Yaxley and Green 1998; Pertermann and Hirschmann 2003; Yaxley and Sobolev 2007; Spandler et al.

Table 3 Experimental feldspar compositions

\begin{tabular}{|c|c|c|c|c|c|c|c|c|c|c|c|c|c|c|c|c|}
\hline $\begin{array}{l}\text { Run no. } \\
\text { Pressure }(\mathrm{GPa}) \\
\text { Temperature }\left({ }^{\circ} \mathrm{C}\right) \\
\text { Analyses }\end{array}$ & $\begin{array}{l}\text { EP1 } \\
3.0 \\
1,100 \\
8\end{array}$ & SD & $\begin{array}{l}\mathrm{EP} 2 \\
3.0 \\
1,150 \\
7\end{array}$ & SD & $\begin{array}{l}\text { EP15 } \\
3.0 \\
1,200 \\
6\end{array}$ & SD & $\begin{array}{l}\text { EP10 } \\
3.0 \\
1,230 \\
8\end{array}$ & SD & $\begin{array}{l}\mathrm{EP} 22 \\
4.0 \\
1,220 \\
13\end{array}$ & SD & $\begin{array}{l}\text { EP12 } \\
4.0 \\
1,250 \\
6\end{array}$ & $\mathrm{SD}$ & $\begin{array}{l}\text { EP16 } \\
5.0 \\
1,250 \\
8\end{array}$ & SD & $\begin{array}{l}\text { EP20 } \\
5.0 \\
1,280 \\
6\end{array}$ & SD \\
\hline \multicolumn{17}{|l|}{ Wt $\%$ oxide } \\
\hline $\mathrm{SiO}_{2}$ & 65.71 & 0.82 & 66.06 & 1.45 & 65.67 & 0.41 & 65.07 & 0.40 & 64.83 & 0.42 & 65.08 & 0.61 & 64.95 & 0.52 & 64.63 & 0.39 \\
\hline $\mathrm{TiO}_{2}$ & 0.30 & 0.11 & 0.23 & 0.06 & $<0.20$ & - & $<0.20$ & - & 0.24 & 0.01 & $<0.20$ & - & $<0.20$ & - & $<0.20$ & - \\
\hline $\mathrm{Al}_{2} \mathrm{O}_{3}$ & 19.10 & 0.21 & 19.69 & 0.62 & 20.13 & 0.44 & 20.48 & 0.22 & 18.41 & 0.32 & 18.59 & 0.19 & 18.39 & 0.23 & 18.46 & 0.16 \\
\hline $\mathrm{Fe}_{2} \mathrm{O}_{3}$ & 0.17 & 0.17 & 0.29 & 0.16 & 0.13 & 0.08 & 0.23 & 0.09 & 0.20 & 0.11 & 0.32 & 0.20 & 0.18 & 0.08 & 0.32 & 0.12 \\
\hline $\mathrm{CaO}$ & 0.74 & 0.12 & 1.69 & 0.14 & 1.48 & 0.13 & 1.97 & 0.17 & 0.06 & 0.06 & 0.18 & 0.06 & 0.10 & 0.03 & 0.06 & 0.04 \\
\hline $\mathrm{Na}_{2} \mathrm{O}$ & 4.78 & 0.38 & 5.54 & 0.32 & 5.66 & 0.09 & 5.78 & 0.13 & 1.31 & 0.06 & 1.58 & 0.06 & 0.83 & 0.12 & 0.84 & 0.05 \\
\hline $\mathrm{K}_{2} \mathrm{O}$ & 8.79 & 0.38 & 6.67 & 0.27 & 6.78 & 0.20 & 6.23 & 0.22 & 14.44 & 0.22 & 14.11 & 0.19 & 15.16 & 0.26 & 14.95 & 0.18 \\
\hline Total & 99.59 & 1.01 & 99.93 & 1.83 & 99.86 & 0.40 & 99.76 & 0.68 & 99.49 & 0.68 & 99.85 & 0.40 & 99.61 & 0.79 & 99.26 & 0.61 \\
\hline \multicolumn{17}{|c|}{ Molecular formula (based on eight oxygens) } \\
\hline $\mathrm{Si}$ & 2.97 & 0.01 & 2.95 & 0.03 & 2.94 & 0.01 & 2.92 & 0.01 & 2.99 & 0.01 & 2.99 & 0.01 & 3.00 & 0.00 & 2.99 & 0.01 \\
\hline $\mathrm{Ti}$ & 0.01 & 0.01 & 0.01 & 0.00 & - & - & - & - & 0.01 & 0.00 & - & - & - & - & - & - \\
\hline $\mathrm{Al}$ & 1.02 & 0.01 & 1.04 & 0.04 & 1.06 & 0.02 & 1.08 & 0.01 & 1.00 & 0.01 & 1.01 & 0.01 & 1.00 & 0.01 & 1.01 & 0.01 \\
\hline $\mathrm{Fe}$ & 0.01 & 0.01 & 0.01 & 0.01 & 0.00 & 0.00 & 0.01 & 0.00 & 0.01 & 0.00 & 0.01 & 0.01 & 0.01 & 0.00 & 0.01 & 0.00 \\
\hline $\mathrm{Ca}$ & 0.04 & 0.01 & 0.08 & 0.01 & 0.07 & 0.01 & 0.09 & 0.01 & 0.00 & 0.00 & 0.01 & 0.00 & 0.00 & 0.00 & 0.00 & 0.00 \\
\hline $\mathrm{Na}$ & 0.42 & 0.04 & 0.48 & 0.02 & 0.49 & 0.01 & 0.50 & 0.01 & 0.12 & 0.01 & 0.14 & 0.01 & 0.07 & 0.01 & 0.08 & 0.00 \\
\hline $\mathrm{K}$ & 0.51 & 0.02 & 0.38 & 0.02 & 0.39 & 0.01 & 0.36 & 0.01 & 0.85 & 0.01 & 0.83 & 0.01 & 0.89 & 0.01 & 0.88 & 0.01 \\
\hline Total cations & 4.98 & 0.02 & 4.95 & 0.03 & 4.95 & 0.01 & 4.96 & 0.01 & 4.98 & 0.05 & 4.98 & 0.04 & 4.97 & 0.04 & 4.98 & 0.01 \\
\hline Anorthite & 7.9 & 1.2 & 14.4 & 1.0 & 12.6 & 0.8 & 15.9 & 1.3 & 2.1 & 2.4 & 5.8 & 1.9 & 6.2 & 1.6 & 4.00 & 2.36 \\
\hline $\mathrm{K} /(\mathrm{Na}+\mathrm{K})$ & 0.55 & 0.03 & 0.44 & 0.01 & 0.44 & 0.01 & 0.41 & 0.01 & 0.88 & 0.01 & 0.86 & 0.01 & 0.92 & 0.01 & 0.92 & 0.00 \\
\hline
\end{tabular}

The 'analyses' row refers to the number of analyses used to calculate the average

$S D$ standard deviation 

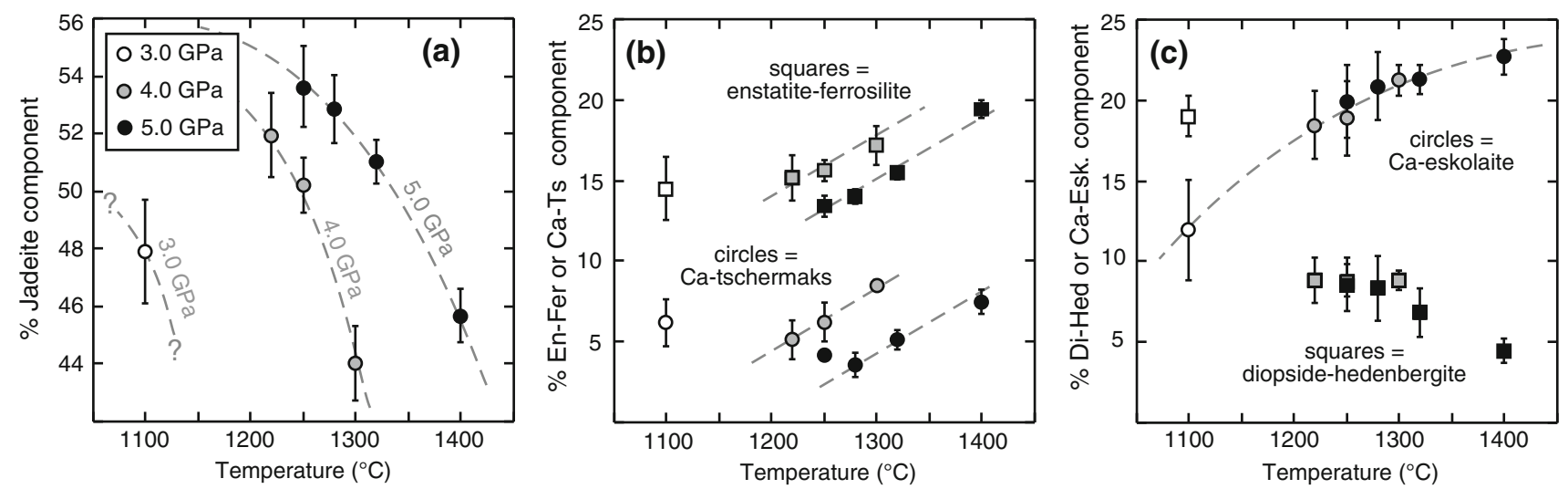

Fig. 4 Experimental clinopyroxene compositions: a Jadeite component; b enstatite-ferrosilite and Ca-tschermaks components; $\mathbf{c} \mathrm{Ca}-$

represent $1 \mathrm{SD}$ of multiple mineral analyses. In many cases, the eskolaite and diopside-hedenbergite components. Error bars

Table 4 Experimental clinopyroxene compositions

\begin{tabular}{|c|c|c|c|c|c|c|c|c|c|c|c|c|c|c|c|c|}
\hline $\begin{array}{l}\text { Run no. } \\
\text { Pressure }(\mathrm{GPa}) \\
\text { Temperature }\left({ }^{\circ} \mathrm{C}\right) \\
\text { Analyses }\end{array}$ & $\begin{array}{l}\text { EP1 } \\
3.0 \\
1,100 \\
5\end{array}$ & SD & $\begin{array}{l}\mathrm{EP} 22 \\
4.0 \\
1,220 \\
11\end{array}$ & SD & $\begin{array}{l}\mathrm{EP} 12 \\
4.0 \\
1,250 \\
8\end{array}$ & SD & $\begin{array}{l}\text { EP11 } \\
4.0 \\
1,300 \\
5\end{array}$ & SD & $\begin{array}{l}\text { EP16 } \\
50 \\
1,250 \\
7\end{array}$ & SD & $\begin{array}{l}\text { EP20 } \\
5.0 \\
1,280 \\
8\end{array}$ & SD & $\begin{array}{l}\text { EP21 } \\
5.0 \\
1,320 \\
9\end{array}$ & SD & $\begin{array}{l}\text { EP17 } \\
5.0 \\
1,400 \\
9\end{array}$ & SD \\
\hline \multicolumn{17}{|l|}{$\mathrm{Wt} \%$ oxide } \\
\hline $\mathrm{SiO}_{2}$ & 54.35 & 0.93 & 55.13 & 0.66 & 54.64 & 0.84 & 53.89 & 0.31 & 55.63 & 0.44 & 55.86 & 0.25 & 55.58 & 0.44 & 54.82 & 0.50 \\
\hline $\mathrm{TiO}_{2}$ & 1.03 & 0.06 & 1.04 & 0.10 & 0.91 & 0.09 & 0.81 & 0.10 & 0.89 & 0.09 & 0.85 & 0.10 & 0.75 & 0.07 & 0.76 & 0.15 \\
\hline $\mathrm{Al}_{2} \mathrm{O}_{3}$ & 17.61 & 0.45 & 19.81 & 0.55 & 19.91 & 0.49 & 20.03 & 0.25 & 20.10 & 0.54 & 19.86 & 0.65 & 20.29 & 0.44 & 20.45 & 0.38 \\
\hline $\mathrm{FeO}$ & 5.52 & 0.74 & 5.13 & 0.32 & 5.40 & 0.23 & 5.53 & 0.29 & 4.55 & 0.23 & 4.85 & 0.28 & 5.15 & 0.15 & 6.08 & 0.36 \\
\hline $\mathrm{MgO}$ & 6.08 & 0.19 & 4.69 & 0.42 & 4.66 & 0.13 & 5.17 & 0.30 & 4.28 & 0.32 & 4.32 & 0.31 & 4.42 & 0.27 & 4.96 & 0.22 \\
\hline $\mathrm{CaO}$ & 8.45 & 0.43 & 6.39 & 0.26 & 6.67 & 0.11 & 7.57 & 0.14 & 6.23 & 0.16 & 6.13 & 0.24 & 6.19 & 0.26 & 6.37 & 0.15 \\
\hline $\mathrm{Na}_{2} \mathrm{O}$ & 7.04 & 0.29 & 7.70 & 0.25 & 7.41 & 0.14 & 6.48 & 0.18 & 7.96 & 0.21 & 7.85 & 0.19 & 7.59 & 0.11 & 6.78 & 0.17 \\
\hline Total & 100.08 & 0.90 & 99.88 & 0.83 & 99.60 & 0.88 & 99.48 & 0.45 & 99.63 & 0.62 & 99.71 & 0.62 & 99.96 & 0.73 & 100.24 & 0.87 \\
\hline \multicolumn{17}{|c|}{ Molecular formula (based on six oxygens) } \\
\hline $\mathrm{Si}$ & 1.91 & 0.01 & 1.92 & 0.01 & 1.91 & 0.01 & 1.89 & 0.00 & 1.93 & 0.00 & 1.94 & 0.01 & 1.93 & 0.01 & 1.90 & 0.00 \\
\hline $\mathrm{Ti}$ & 0.03 & 0.00 & 0.03 & 0.00 & 0.02 & 0.00 & 0.02 & 0.00 & 0.02 & 0.00 & 0.02 & 0.00 & 0.02 & 0.00 & 0.02 & 0.00 \\
\hline $\mathrm{Al}$ & 0.73 & 0.02 & 0.81 & 0.02 & 0.82 & 0.02 & 0.83 & 0.01 & 0.82 & 0.02 & 0.81 & 0.02 & 0.83 & 0.02 & 0.84 & 0.01 \\
\hline $\mathrm{Fe}$ & 0.16 & 0.02 & 0.15 & 0.01 & 0.16 & 0.01 & 0.16 & 0.01 & 0.13 & 0.01 & 0.14 & 0.01 & 0.15 & 0.00 & 0.18 & 0.01 \\
\hline $\mathrm{Mg}$ & 0.32 & 0.01 & 0.24 & 0.02 & 0.24 & 0.01 & 0.27 & 0.02 & 0.22 & 0.02 & 0.22 & 0.02 & 0.23 & 0.01 & 0.26 & 0.01 \\
\hline $\mathrm{Ca}$ & 0.32 & 0.02 & 0.24 & 0.01 & 0.25 & 0.00 & 0.28 & 0.00 & 0.23 & 0.01 & 0.23 & 0.01 & 0.23 & 0.01 & 0.24 & 0.01 \\
\hline $\mathrm{Na}$ & 0.48 & 0.02 & 0.52 & 0.01 & 0.50 & 0.01 & 0.44 & 0.01 & 0.54 & 0.01 & 0.53 & 0.01 & 0.51 & 0.01 & 0.46 & 0.01 \\
\hline Total cations & 3.94 & 0.02 & 3.91 & 0.01 & 3.91 & 0.01 & 3.89 & 0.00 & 3.90 & 0.01 & 3.90 & 0.01 & 3.89 & 0.00 & 3.89 & 0.01 \\
\hline Mg\# & 66.3 & 2.5 & 61.9 & 1.5 & 60.6 & 0.7 & 62.5 & 1.4 & 62.6 & 1.5 & 61.4 & 1.4 & 60.5 & 1.1 & 59.3 & 2.0 \\
\hline Jadeite & 47.9 & 1.8 & 51.9 & 1.5 & 50.2 & 0.9 & 44.0 & 1.3 & 53.6 & 1.4 & 52.8 & 1.2 & 51.0 & 0.8 & 45.7 & 1.0 \\
\hline Ca Eskolaite & 11.9 & 3.1 & 18.4 & 2.1 & 18.9 & 2.3 & 21.2 & 0.9 & 19.9 & 2.3 & 20.8 & 2.1 & 21.3 & 0.9 & 22.6 & 1.1 \\
\hline Ca-Tschermaks & 6.2 & 1.5 & 5.1 & 1.2 & 6.2 & 1.2 & 8.5 & 0.3 & 4.1 & 0.3 & 3.5 & 0.7 & 5.1 & 0.6 & 7.5 & 0.8 \\
\hline Diop-Ferros & 19.0 & 1.3 & 8.8 & 1.4 & 8.8 & 1.0 & 8.8 & 0.6 & 8.5 & 1.6 & 8.3 & 2.0 & 6.8 & 1.5 & 4.4 & 0.7 \\
\hline Enst-Hed & 14.5 & 2.0 & 15.1 & 1.4 & 15.6 & 0.7 & 17.1 & 1.2 & 13.4 & 0.7 & 14.0 & 0.5 & 15.4 & 0.4 & 19.4 & 0.6 \\
\hline
\end{tabular}

The 'analyses' row refers to the number of analyses used to calculate the average. Molecular formulas calculated on the basis of charge balance. All $\mathrm{Fe}$ in clinopyroxene is assumed to be $\mathrm{Fe}^{2+}$. See text for analytical details

$S D$ standard deviation

2008). $\mathrm{TiO}_{2}$ contents vary little, lying between 1.1 and 0.75 wt $\%$. Jadeite contents increase with pressure and decrease with increasing melt fraction (Fig. 4a). In contrast,
Ca-tschermaks and enstatite-ferrosilite components show no pressure dependence and increase with increasing melt fraction (Fig. 4b). Calculated molecular formulae for 
clinopyroxenes always give cation totals significantly less than 4.0 (Table 4), which are not analytical artefacts, but are attributed to the present of a Ca-eskolaite $\left(\mathrm{Ca}_{0.5}[]_{0.5} \mathrm{AlSi}_{2} \mathrm{O}_{6}\right)$ component (Konzett et al. 2008 and references therein). Ca-eskolaite is regarded as a high pressure substitution in clinopyroxene, although in this case we observe no clear pressure effect (Fig. 4c). Nonetheless, Ca-eskolaite contents increase with temperature up to $23 \mathrm{~mol} \%$ at $1,400^{\circ} \mathrm{C}$. Diopside-hedenbergite contents decrease with temperature from $19 \mathrm{~mol} \%$ at $1,100^{\circ} \mathrm{C}, 3.0 \mathrm{GPa}$ to below $5 \mathrm{~mol} \%$ at $1,400^{\circ} \mathrm{C}, 5.0 \mathrm{GPa}$.

\section{Garnet}

In general, the experimental garnets are almandine- and pyrope-rich, with low $\mathrm{TiO}_{2}(<0.9 \mathrm{wt} \%)$ and spessartine $(<1.2 \mathrm{~mol} \%)$ contents (Table 5). While feldspar and/or clinopyroxene are still stable, garnet modes (Table 1) and compositions (Fig. 5) undergo relatively minor changes with increasing temperature. Notably, grossular contents remain fixed at $14-15 \mathrm{~mol} \%$ while clinopyroxene is present. However, there is a rapid progression to pyrope-rich and almandine- and grossular-poor compositions with increasing melt fraction once feldspar and/or clinopyroxene are melted out. Pressure has little effect on garnet compositions, although garnet in experiments at $3.0 \mathrm{GPa}$ and low melt fractions is relatively almandine poor and grossular and pyrope rich due to the absence of clinopyroxene.

\section{Melt}

Dacitic melts were produced in all supersolidus experiments, with highly alkaline compositions formed at melt fractions below $60 \%$ (Table 2; Fig. 6). $\mathrm{SiO}_{2}$ contents show little variation from $67.5 \mathrm{wt} \%$ at low melt fractions $(<30 \%)$, decreasing to around $65 \mathrm{wt} \%$ at complete dissolution of garnet and kyanite ( $\sim 90 \%$ melting). At higher temperatures, quartz/coesite is gradually dissolved, and the melt approaches the bulk starting composition (Fig. 7; Table 2). Glass $\mathrm{Al}_{2} \mathrm{O}_{3}$ concentrations also do not vary greatly, although a shift to lower $\mathrm{Al}_{2} \mathrm{O}_{3}$ contents occurs at the higher pressures (Fig. 6a). Both $\mathrm{TiO}_{2}$ (Fig. 6b) and $\mathrm{P}_{2} \mathrm{O}_{5}$ are strongly incompatible, which is consistent with the rapid melting of rutile and apatite at the solidus. In contrast, both $\mathrm{MgO}$ and $\mathrm{FeO}$ behave compatibly (Fig. 6c). At $3.0 \mathrm{GPa}, \mathrm{MgO}$ and $\mathrm{FeO}$ contents of the melts remain low until feldspar is melted out at $60 \%$ melting. At intermediate melt fractions (30-70\%), melt $\mathrm{MgO}$ and $\mathrm{FeO}$ contents increase with increasing pressure (Fig. 7).

At melt fractions below $60 \%$ there are striking variations in melt $\mathrm{CaO}, \mathrm{Na}_{2} \mathrm{O}$ and $\mathrm{K}_{2} \mathrm{O}$ as a function of pressure (Fig. 6d-f). At 3.0 GPa where melt coexists with feldspar, melt $\mathrm{Na}_{2} \mathrm{O}$ contents remain constant at $\sim 4.0 \mathrm{wt} \%, \mathrm{CaO}$ contents increase slightly, and $\mathrm{K}_{2} \mathrm{O}$ contents decrease slightly. With increasing pressure and the stabilisation of clinopyroxene (Fig. 1), $\mathrm{CaO}$ and $\mathrm{Na}_{2} \mathrm{O}$ become increasingly more compatible, as also found by Schmidt et al. (2004) and Thomsen and Schmidt (2008). In complete contrast, $\mathrm{K}_{2} \mathrm{O}$ contents of the low-degree melts increase markedly with pressure, with low-degree melts at 5.0 GPa approaching ultrapotassic compositions (Figs. 6f, 7). At high melt fractions ( $>60 \%$ melt), where clinopyroxene and feldspar are no longer present, $\mathrm{CaO}, \mathrm{Na}_{2} \mathrm{O}$ and $\mathrm{K}_{2} \mathrm{O}$ behave incompatibly, and no distinction in melt composition with pressure can be discerned from these elements.

\section{Discussion}

Modification of sedimentary rocks during transport into the mantle

Estimates of the total amount of sedimentary material subducted over geological time are around $0.5 \%$ of the volume of the upper mantle (Jackson et al. 2007). Based on currently subducting sedimentary packages, most of this material is likely to be of terrigenous origin (Plank and Langmuir 1998). Delamination and foundering of the lower portions of overthickened continental crust (e.g., Ducea 2002) may also draw metasedimentary rocks into the mantle, as the lower crust is also known to contain a proportion of metasediments (Rudnick and Gao 2003). Our results have implications for the ultimate fate of these materials, but first we evaluate the degree of chemical modification that sedimentary materials are expected to undergo during subduction.

The almost ubiquitous observation of the slab geochemical signature in arc magmas has lead to an assumption that subducting crustal rocks undergo extensive geochemical modification during subduction (e.g., Tatsumi 2005). Both mafic and metasedimentary crustal rocks will undergo extensive dehydration during subduction to depths of $\sim 70 \mathrm{~km}$ (e.g., Kerrick and Connolly 2001; Schmidt and Poli 2003), but experimental studies indicate that these liberated fluids will be dilute and impart little geochemical modification to the rock (Spandler et al. 2007; Hermann and Spandler 2008). This is supported by the fact that HP and UHP metasediments have compositions that are directly comparable to their unmetamorphosed counterparts (Busigny et al. 2003; Spandler et al. 2003; Kelemen et al. 2007; Schertl and Schreyer 2008). Instead, most studies on natural HP and UHP samples of previously subducted crust and relevant experimental studies indicate that significant element loss from crustal rocks subducted to at least $200 \mathrm{~km}$ depth is likely only in regions of 
Table 5 Experimental garnet compositions

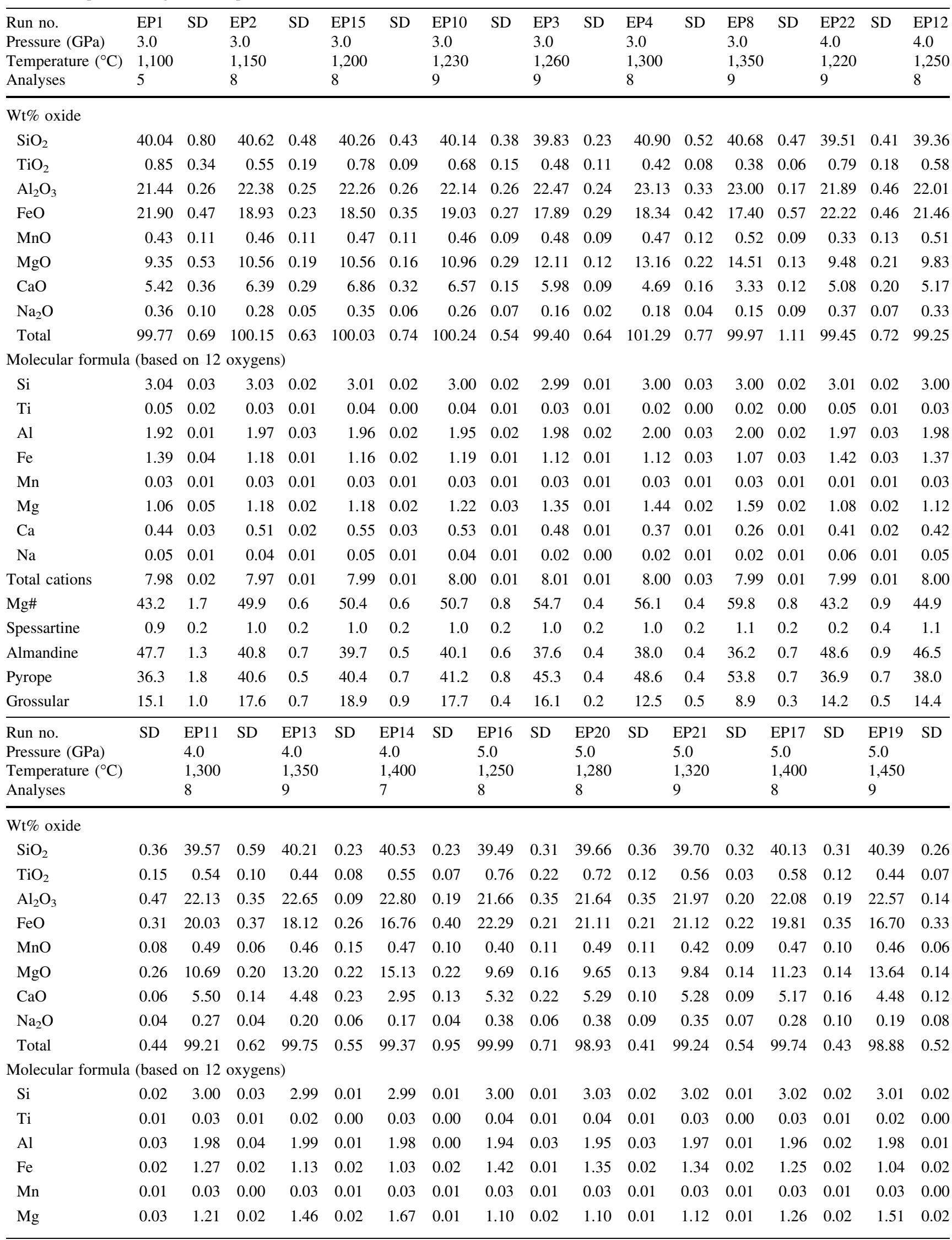


Table 5 continued

\begin{tabular}{|c|c|c|c|c|c|c|c|c|c|c|c|c|c|c|c|c|c|}
\hline $\begin{array}{l}\text { Run no. } \\
\text { Pressure }(\mathrm{GPa}) \\
\text { Temperature }\left({ }^{\circ} \mathrm{C}\right) \\
\text { Analyses }\end{array}$ & SD & $\begin{array}{l}\text { EP11 } \\
4.0 \\
1,300 \\
8\end{array}$ & SD & $\begin{array}{l}\text { EP13 } \\
4.0 \\
1,350 \\
9\end{array}$ & SD & $\begin{array}{l}\text { EP14 } \\
4.0 \\
1,400 \\
7\end{array}$ & SD & $\begin{array}{l}\text { EP16 } \\
5.0 \\
1,250 \\
8\end{array}$ & SD & $\begin{array}{l}\text { EP20 } \\
5.0 \\
1,280 \\
8\end{array}$ & SD & $\begin{array}{l}\mathrm{EP} 21 \\
5.0 \\
1,320 \\
9\end{array}$ & SD & $\begin{array}{l}\text { EP17 } \\
5.0 \\
1,400 \\
8\end{array}$ & SD & $\begin{array}{l}\text { EP19 } \\
5.0 \\
1,450 \\
9\end{array}$ & SD \\
\hline $\mathrm{Ca}$ & 0.00 & 0.45 & 0.01 & 0.36 & 0.02 & 0.23 & 0.01 & 0.43 & 0.02 & 0.43 & 0.01 & 0.43 & 0.01 & 0.42 & 0.01 & 0.36 & 0.01 \\
\hline $\mathrm{Na}$ & 0.01 & 0.04 & 0.01 & 0.03 & 0.01 & 0.02 & 0.01 & 0.06 & 0.01 & 0.06 & 0.01 & 0.05 & 0.01 & 0.04 & 0.01 & 0.03 & 0.01 \\
\hline Total & 0.02 & 8.00 & 0.02 & 8.01 & 0.01 & 8.00 & 0.01 & 8.01 & 0.01 & 7.98 & 0.01 & 7.99 & 0.01 & 7.99 & 0.01 & 7.99 & 0.02 \\
\hline Mg\# & 0.7 & 48.7 & 0.7 & 56.5 & 0.5 & 61.7 & 0.4 & 43.7 & 0.3 & 44.9 & 0.5 & 45.4 & 0.5 & 50.3 & 0.4 & 59.3 & 0.5 \\
\hline pe & 0.2 & 1 & 0.1 & 0 & 0.3 & 1.0 & 0.2 & .9 & 0.2 & 11 & 0.2 & 0.9 & 0.2 & 1.0 & 0.2 & 1.0 & 0.1 \\
\hline Aln & 0.5 & 43.0 & 0.6 & 37.9 & 0.5 & 34.9 & 0. & 47.7 & 0.3 & 46.3 & 0.4 & 46.1 & 0.5 & 42.2 & 0.4 & 35.4 & 0.5 \\
\hline Pyrope & 0.7 & 40.9 & 0.6 & 49.2 & 0.6 & 56.2 & 0.5 & 36.9 & 0.4 & 37.7 & 0.4 & 38.2 & 0.4 & 42.7 & 0.4 & 51.5 & 0.4 \\
\hline Grossular & 0.3 & 15.1 & 0.3 & 12.0 & 0.6 & 7.9 & 0.3 & 14.6 & 0.5 & 14.9 & 0.3 & 14.8 & 0.2 & 14.1 & 0.5 & 12.2 & 0.3 \\
\hline
\end{tabular}

The 'analyses' row refers to the number of analyses used to calculate the average. Molecular formulas calculated on the basis of charge balance. All $\mathrm{Fe}$ in garnet is assumed to be $\mathrm{Fe}^{2+}$. See text for analytical details

$S D$ standard deviation
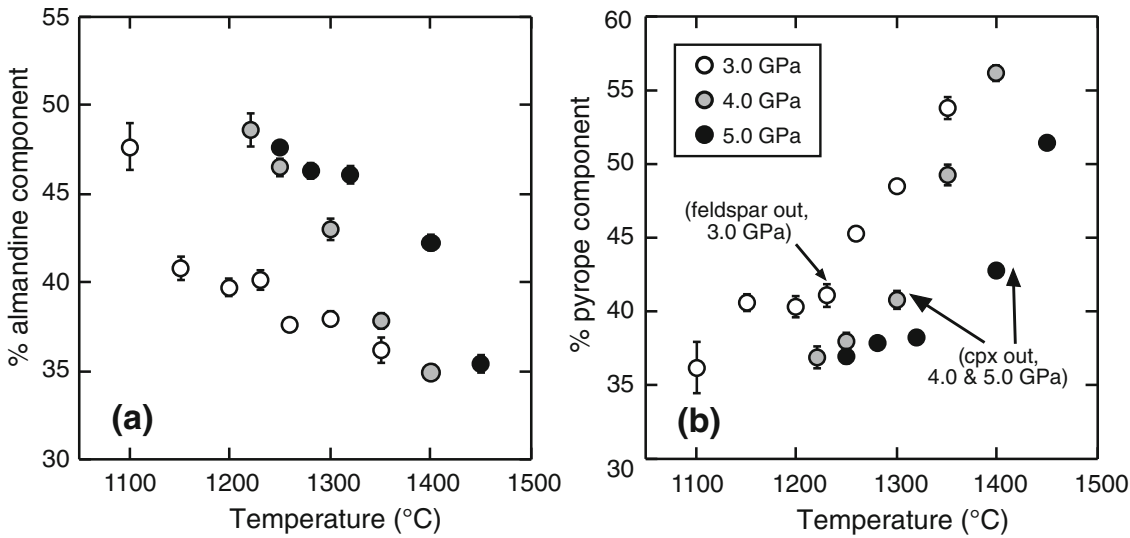

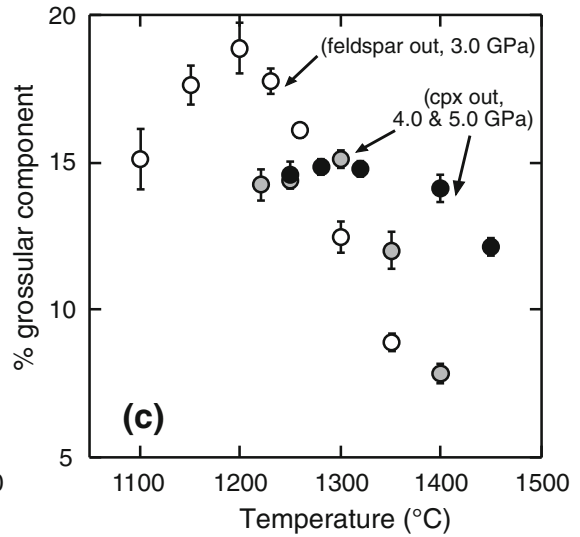

Fig. 5 Experimental garnet compositions: a almandine component; b pyrope component; $\mathbf{c}$ grossular component. Note the marked increase in the pyrope contents and decrease in grossular contents once feldspar is melted out at $3.0 \mathrm{GPa}$ and clinopyroxene (cpx) is melted

mélange formation (Bebout and Barton 2002) or in zones of localised high fluid/rock interaction in the slab (Hermann et al. 2006; Zack and John 2007). Experimental evidence suggests that significant mass flux from these rocks in subduction zones requires fluid-fluxed melting which can only occur in response to influx of external fluids (Hermann et al. 2006; Hermann and Spandler 2008; Thomsen and Schmidt 2008). Most available data indicate that fluid flow would be highly channelised (e.g., Zack and John 2007), meaning that a large proportion of the rock mass would avoid fluid/rock interaction, and hence, significant chemical modification. Support for this hypothesis has come from a recent Nd-Hf isotopic study of the IzuMariana arc system by Chauvel et al. (2009), which shows that at least $85 \%$ of the $\mathrm{Nd}$ (and $\mathrm{Hf}$ ) of subducted sediments escape mass fluxing into arc magmas to be recycled into the mantle. As the fluid/solid partitioning of $\mathrm{Nd}$ in the out at 4.0 and 5.0 GPa. Error bars represent $1 \mathrm{SD}$ of multiple mineral analyses. In some cases, the error bars are smaller than the plotted symbols

crustal rocks at sub-arc depths is expected to be close to unity or slightly fluid mobile (Kessel et al. 2005; Klimm et al. 2008, Hermann and Rubatto 2009), this observation is most easily reconciled with limited fluid-rock interaction and limited chemical modification of subducted sediments down to sub-arc depths.

The fate of sediments subducted to beyond $200 \mathrm{~km}$ depth cannot be evaluated from natural samples, as these are not available at the Earth's surface. Fortunately a wealth of experimental studies over the last two decades (Domanik and Holloway 1996; Ono 1998; Hermann and Green 2001; Schmidt and Poli 2003; Schmidt et al. 2004, Hermann and Spandler 2008), combined with top slab temperature modelling (Kincaid and Griffiths 2004, Abers et al. 2006) provides the phase petrology and physical conditions needed to assess the potential for deep chemical modifications. In UHP metasedimentary rocks, water is 
Fig. 6 Experimental melt compositions (wt\% oxides) as a function of pressure and melt fraction: a $\mathrm{Al}_{2} \mathrm{O}_{3} ; \mathbf{b} \mathrm{TiO}_{2}$; c $\mathrm{FeO}+\mathrm{MgO} ; \mathbf{d ~} \mathrm{CaO} ;$ e $\mathrm{Na}_{2} \mathrm{O}$; f $\mathrm{K}_{2} \mathrm{O}$. The thick grey line at $\sim 90 \%$ melting refers to the point where quartz/coesite becomes the sole liquidus phase. Note the contrasting behaviour of $\mathrm{Na}_{2} \mathrm{O}$ and $\mathrm{K}_{2} \mathrm{O}$ at melt fractions below $60 \%$. Error bars represent $1 \mathrm{SD}$ of multiple glass analyses. In some cases, the error bars are smaller than the plotted symbols
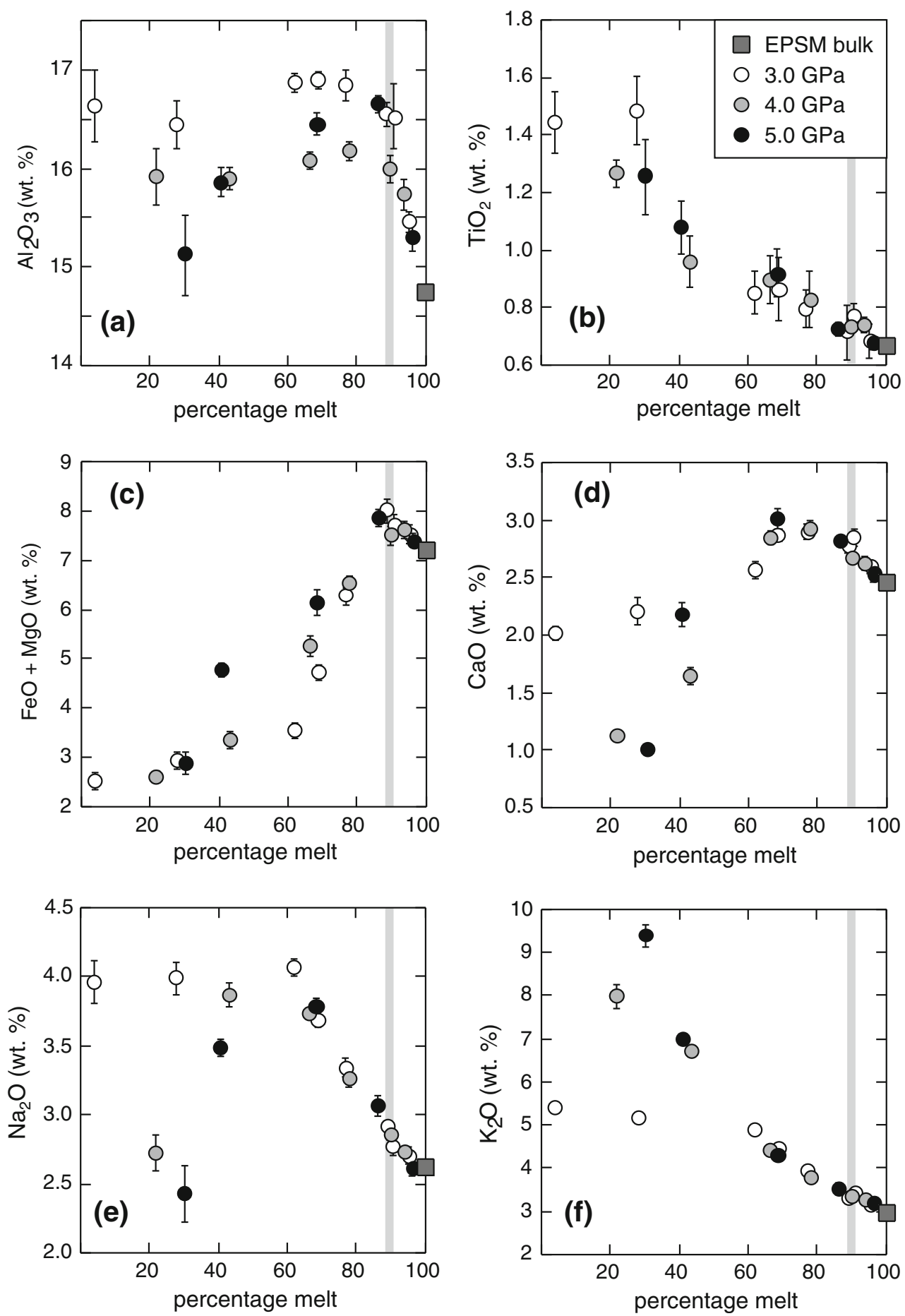

dominantly hosted by phengite, which is stable in slabs at very high temperatures (Domanik and Holloway 1996; Ono 1998). Therefore, fluid liberation from metasediments at depths greater than $\sim 100 \mathrm{~km}$ will occur in response to phengite breaking down to K-hollandite at 7-9 GPa, $\sim 900-1,000^{\circ} \mathrm{C}$ (Schmidt and Poli 2003). Based on experiments on water-saturated pelite, Schmidt et al. (2004) suggested that most of the $\mathrm{K}_{2} \mathrm{O}$ (i.e., one of the most fluid mobile elements) would be dissolved out of the rock by the fluids produced at these conditions. However, it remains uncertain whether the fluid produced by phengite dehydration alone would be sufficient to remove all of the rock $\mathrm{K}_{2} \mathrm{O}$.

The proportion of phengite in subducted sediments is likely to be highly variable, as phengite is the primary host of $\mathrm{K}_{2} \mathrm{O}$, and subducting sediments vary significantly in 


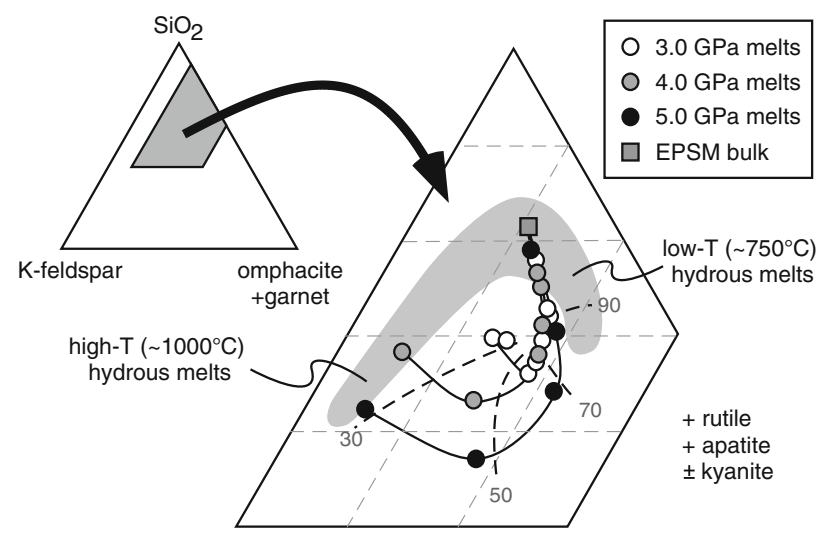

Fig. 7 Experimental melt compositions projected onto a omphacite + garnet $-\mathrm{K}$-feldspar $-\mathrm{SiO}_{2}$ ternary diagram. Mineral compositions at the apices of the diagram are $\mathrm{KAlSi}_{3} \mathrm{O}_{8}$ for $\mathrm{K}$-feldspar, $\mathrm{CaNaMgAlSi}_{2} \mathrm{O}_{6}$ for omphacite and $\left(\mathrm{FeMg}_{3} \mathrm{Al}_{2} \mathrm{Si}_{3} \mathrm{O}_{12}\right.$ for garnet. The dashed lines with numbers refer to percentage melting. Note that the low-degree $(<50 \%)$ melt compositions shift to higher K-feldspar components with increasing pressure. Above $90 \%$ melting the melt trends are entirely controlled by dissolution of quartz/coesite. The grey field of hydrous melts are from experiments on water-saturated melting of EPSM by Hermann and Spandler (2008). Note the trend from low-K to high-K melts with increasing temperature for the hydrous melts

their $\mathrm{K}_{2} \mathrm{O}$ content $(<0.4$ to $>4.0$ wt $\%$; Plank and Langmuir 1998). Therefore, we evaluate $\mathrm{K}_{2} \mathrm{O}$ loss during high- $\mathrm{P}$ phengite breakdown by considering $\mathrm{K}_{2} \mathrm{O} / \mathrm{H}_{2} \mathrm{O}$ ratios. Phengite has a $\mathrm{K}_{2} \mathrm{O} / \mathrm{H}_{2} \mathrm{O}$ of around 2.5. The composition of the fluid phase produced during phengite breakdown can be extrapolated from the experimental work of Hermann and Spandler (2008) (see their Figure 10a) to be between 0.1 and 0.5. Based on these figures, less than $20 \%$ of the $\mathrm{K}_{2} \mathrm{O}$ inventory of the rock would be removed by the fluid produced by phengite breakdown, a value that is insignificant compared to the primary variability in $\mathrm{K}_{2} \mathrm{O}$ content of subducted sediments. An indication that these calculations overestimate the amount of $\mathrm{K}_{2} \mathrm{O}$ that will be dissolved in a fluid come from high $\mathrm{P}$ synthesis experiments on a waterrich sediment composition (MAG-1) by Rapp et al. (2008). This composition has a $\mathrm{K}_{2} \mathrm{O} / \mathrm{H}_{2} \mathrm{O}$ of 0.5 , yet abundant $\mathrm{K}$ hollandite is formed in the anhydrous assemblage at $P-T$ conditions of up to $16 \mathrm{GPa}$ and $1,450^{\circ} \mathrm{C}$. Only at higher temperatures and pressures do Rapp et al. (2008) find that the fluid phase becomes the dominant host for incompatible elements, but again in nature we would expect that interaction of fluid and metasediments at these conditions would only occur in response to influxing of external fluids.

To summarise, the available data from HP and UHP rocks and experimental studies suggest that a significant, if not dominant, proportion of subducting sedimentary material undergoes minimal geochemical modification during metamorphic devolatilisation. These rocks can lose all, or almost all, of their original $\mathrm{H}_{2} \mathrm{O}$ content during subduction (Ono 1998), meaning that anhydrous pelitic compositions may be present as significant bodies in the mantle. The subsequent fate of these rocks can be assessed using the phase relations and melting conditions determined in the present study.

High pressure melting of metasedimentary rocks

Our results, combined with other relevant experimental work, can be used to infer some general conditions of melting of metasedimentary rocks in the upper mantle. Anhydrous pelite solidus temperatures of $1,150-1,200^{\circ} \mathrm{C}$ at 3.0 $\mathrm{GPa}$ and $1,250-1,280^{\circ} \mathrm{C}$ at $5.0 \mathrm{GPa}$ (Fig. 2) are broadly consistent with the estimated dry solidus for granite of Stern and Wyllie (1973) and the experimentally determined solidus for an upper continental crust composition at pressures above 5.0 GPa (Irifune et al. 1994). Melting of $\mathrm{H}_{2} \mathrm{O}$-undersaturated pelite at 3.0-5.0 GPa, with or without $\mathrm{CO}_{2}$ present, is expected to occur in response to phengite dissolution at temperatures of between 950 and $1,100^{\circ} \mathrm{C}$ (Hermann and Green 2001; Thomsen and Schmidt 2008); temperatures that are $200-250^{\circ} \mathrm{C}$ lower than anhydrous melting conditions. At these pressures, the presence of $\mathrm{CO}_{2}$ seemingly has little effect on initial melting conditions (Thomsen and Schmidt 2008). Water saturated or wet melting of sedimentary compositions occurs at even lower temperatures $\left(350-500^{\circ} \mathrm{C}\right.$ below the anhydrous solidus; Nichols et al. 1994; Schmidt et al. 2004; Hermann and Spandler 2008), although it is likely that the wet solidus for pelitic compositions terminates between 3.5 and $5.5 \mathrm{GPa}$ at the second critical endpoint (Schmidt et al. 2004; Hermann and Spandler 2008). Compared to the anhydrous pelite melts, water-saturated melting of pelite produces melts with higher $\mathrm{SiO}_{2}$ (68-77 vs. 65-68 wt\%) and lower $\mathrm{FeO}+\mathrm{MgO}$ contents (Fig. 7; Schmidt et al. 2004; Hermann and Spandler 2008).

Experimental constraints on high-pressure liquidus temperatures, and hence total melting intervals, for sedimentary compositions are limited, but important relations can be inferred from studies of granitic compositions by Stern and Wyllie (1973) and Stern et al. (1975). These workers reported narrow melting intervals of around $100^{\circ} \mathrm{C}$ for granite with excess water at pressures above $3.0 \mathrm{GPa}$, although liquidus temperatures and melting intervals were shown to increase dramatically with decreasing water contents (Stern and Wyllie 1973). Moreover, Stern and Wyllie (1973) inferred that the melting interval for dry granite increases significantly with pressure, due to the shallow $\mathrm{d} P / \mathrm{d} T$ of the liquidus surface. Extrapolation to $5.0 \mathrm{GPa}$ gives dry granite liquidus temperatures in excess of $1,700^{\circ} \mathrm{C}$. Quartz/coesite is the liquidus phase at all reported conditions (Stern et al. 1975). For a water-saturated pelagic red clay, Nichols et al. (1994) reported similar 
solidus and liquidus temperatures to those of wet granite, albeit with an increasing melting interval (to $\sim 200^{\circ} \mathrm{C}$ ) for the red clay at the highest investigated pressure of 3.0 GPa. Quartz remained a residual phase to within $30^{\circ} \mathrm{C}$ of the liquidus for this composition, despite the fact that this composition only contains $15 \%$ normative quartz.

From our experiments, we find the melting interval for dry pelite between 3.0 and $5.0 \mathrm{GPa}$ to be around $400^{\circ} \mathrm{C}$ (Fig. 2), largely due to the extensive stability of liquidus quartz/coesite over $\sim 200^{\circ} \mathrm{C}$. The liquidus temperatures are over $1,550^{\circ} \mathrm{C}$ at these pressures and are consistent with extrapolation from the dry granite liquidus from Stern et al. (1975). Experiments at higher pressures on an upper continental crust by Irifune et al. (1994) identified either coesite or stishovite as the liquidus phase for most of their investigated pressure conditions. Overall, the available experimental data indicate that a silica phase (quartz/coesite/stishovite) is the liquidus phase for a range of hydrous and anhydrous siliceous sedimentary compositions from 1 to $24 \mathrm{GPa}$. Anhydrous compositions are expected to have relatively high liquidus temperatures and extensive melting intervals.

Phase and melting reactions of dry pelite in the upper mantle

Clinopyroxene tends to be absent from high-grade metamorphic assemblages of the pelite composition and makes its appearance with increasing pressure due to reactions of plagioclase components with garnet (including reaction 1 below). In the subsolidus experiments at $3 \mathrm{GPa}$ clinopyroxene is present at $1,100^{\circ} \mathrm{C}$ but absent at $1,150^{\circ} \mathrm{C}$ (Fig. 2), which is consistent with well-known reaction albite $=$ jadeite + quartz (Holland 1980). However, in our case we are not dealing with pure albite and jadeite, rather alkali feldspar and omphacite, and further work is warranted to investigate feldspar and pyroxene stability relations in Na-, K- and Ca-bearing systems. In the case of our pelitic composition, the clinopyroxene-out reaction is accompanied by a decrease in the amount of kyanite and quartz (Table 1), the formation of grossular- and pyroperich garnet (Fig. 5) and the formation of more Na-rich feldspar (Fig. 3). The general reaction (Eq. 1) can be expressed as follows:

$$
\begin{gathered}
6\left[\mathrm{Na}_{0.5} \mathrm{Ca}_{0.5} \mathrm{Mg}_{0.5} \mathrm{Al}_{0.5} \mathrm{Si}_{2} \mathrm{O}_{6}\right]+\underset{\text { omphacite }}{2\left[\mathrm{Al}_{2} \mathrm{SiO}_{5}\right]}+\underset{\text { yanite }}{\mathrm{SiO}_{2}} \\
=2\left[\mathrm{Ca}_{1.5} \mathrm{Mg}_{1.5} \mathrm{Al}_{2} \mathrm{Si}_{3} \mathrm{O}_{12}\right]+\underset{\text { garnet }}{\text { feldspar }} \\
\left.=2 \mathrm{NaAlSi}_{3} \mathrm{O}_{8}\right]
\end{gathered}
$$

At $3.0 \mathrm{GPa}$, initial melting of pelite is largely controlled by feldspar and quartz, allowing rapid melting, up to $60 \%$, within $100^{\circ} \mathrm{C}$ of the solidus until feldspar is exhausted (Fig. 2). Garnet and kyanite only play a minor role in this melting process, which is reflected in the similar compositions (Fig. 5) and modal proportions of these minerals (Table 1) across this melting interval. As feldspar is the sole mineral host for $\mathrm{K}$ and $\mathrm{Na}$, the produced melts are dacitic with $\mathrm{K}_{2} \mathrm{O} / \mathrm{Na}_{2} \mathrm{O}$ close to that of the starting composition.

With increasing pressure above $3.0 \mathrm{GPa}$, the supersolidus stability field of clinopyroxene expands, whereas the feldspar stability field shrinks. Sodium is increasingly partitioned into clinopyroxene, leading to more K-rich feldspar (Fig. 3) and more jadeite-rich clinopyroxene (Fig. 4), as also observed in the subsolidus phase relations of adamellite by Green and Lambert (1965). In the present study, we also examine the influence of this partitioning behaviour on the compositions of low-fraction melts of pelite. With increasing pressure, the melt productivity at low melt fractions decreases (Fig. 2), and ultrapotassic dacite melts are formed due to the preferential fusion of K-feldspar over clinopyroxene (Fig. 7). Again, garnet and kyanite are not significantly involved in the melting reactions.

High $\mathrm{K}_{2} \mathrm{O} / \mathrm{Na}_{2} \mathrm{O}$ melts were also produced by highpressure melting of $\mathrm{H}_{2} \mathrm{O}$ - and $\mathrm{CO}_{2}$-bearing pelite by Thomsen and Schmidt (2008) and Hermann and Spandler (2008), except in these cases phengite, rather than $\mathrm{K}$-feldspar, was the K-bearing mineral. The water-saturated experiments by Hermann and Spandler (2008) were designed to keep water contents (and hence melt \%) close to constant across the range of pressures and temperatures investigated, and, in this case, $\mathrm{K}_{2} \mathrm{O} / \mathrm{Na}_{2} \mathrm{O}$ contents of the melts are primarily controlled by temperature. This contrasts with our results on anhydrous pelite melting, where pressure is the dominant control on variations in melt $\mathrm{K}_{2} \mathrm{O}$ / $\mathrm{Na}_{2} \mathrm{O}$.

In our experiments, clinopyroxene becomes the most important melting phase once K-feldspar is melted out. Irrespective of pressure effects, jadeite and diopside/ hedenburgite contents of clinopyroxene decrease with increasing temperature and, hence, melting (Fig. 4). On the other hand, the Ca-eskolaite component clearly increases with temperature, with the Ca-eskolaite contents of $\sim 23 \mathrm{~mol} \%$ at $5.0 \mathrm{GPa}$ and $1,400^{\circ} \mathrm{C}$ (experiment $\mathrm{EP} 17$ ) being among the highest Ca-eskolaite contents recorded in nature or experiment. There is also a small but significant increase in enstatite-ferrosilite and Ca-tschermaks with temperature (Fig. 4b). Ca-eskolaite has been reported as a significant component in many high pressure experimental clinopyroxenes (Yaxley and Green 1998; Pertermann and Hirschmann 2003; Yaxley and Sobolev 2007; Hermann and Spandler 2008; Konzett et al. 2008; Spandler et al. 2008), and is known to have a strong temperature dependence (Schmidt et al. 2004; Hermann and Spandler 2008; Konzett et al. 2008; this study). Here, and in some other 
studies (e.g., Hermann and Spandler 2008; Konzett et al. 2008), no significant influence of pressure on Ca-eskolaite content is observed. In contrast, clinopyroxene from experiments on mafic eclogites by Yaxley and Sobolev (2007) and Spandler et al. (2008) showed an increase in Ca-eskolaite with pressure. In the latter case, there is a clear inverse relationship between Ca-tschermaks and Ca-eskolaite components (see Fig. 7 of Spandler et al. 2008), which is consistent with the reaction Ca-tschermaks $+\mathrm{SiO}_{2}=$ Ca-eskolaite (see also Konzett et al. 2008). However, in the present study we observe both Ca-tschermaks and Ca-eskolaite components increasing with temperature (Fig. 4). Kyanite has been suggested to influence the stability of Ca-eskolaite (Konzett et al. 2008), but in our experiments the modal proportion of kyanite does not change during clinopyroxene melting (Table 1), indicating kyanite is not significantly involved in the melting reactions. Instead, Ca-eskolaite formation can be ascribed to incongruent melting of diopside/hedenbergite and jadeite components to form $\mathrm{Ca}$-eskolaite, $\mathrm{Ca}$-tschermaks and enstatite/ferrosilite. From the changes in clinopyroxene compositions with temperature (Fig. 4), the clinopyroxene melting reaction (Eq. 2) can be generalised as follows:

$$
\begin{aligned}
2 \text { diopside }+4 \text { jadeite }= & 2 \text { Ca-eskolaite }+ \text { Ca-Tschermak } \\
& + \text { enstatite } / \text { ferrosilite } \\
& + \text { Na-bearing melt }
\end{aligned}
$$

In our experiments, melting of clinopyroxene is also accompanied by consumption of coesite and, at $5.0 \mathrm{GPa}$, minor almandine (Table 1; Figs. 4, 7) to produce dacitic melts with higher $\mathrm{Fe}$ and $\mathrm{Na}$ contents than the lower degree melts (Fig. 6). At all investigated pressures, significant melting of garnet and kyanite only occurs at high melt fractions once feldspar and clinopyroxene are melted out. Under these melting conditions garnet compositions become progressively pyrope rich (Fig. 4).

Phase and melting relations of sedimentary compositions at pressures above $6 \mathrm{GPa}$ have been investigated by Irifune et al. (1994), Ono (1998) and Rapp et al. (2008). At close to $9 \mathrm{GPa}$, coesite converts to stishovite and feldspar is replaced by K-hollandite. At even higher pressures (>13 GPa), components of clinopyroxene are progressively incorporated into garnet as a majorite component and melting is expected to primarily involve jadeite, stishovite and garnet to produce andesitic melts with very low $\mathrm{K}_{2} \mathrm{O}$ / $\mathrm{Na}_{2} \mathrm{O}$ contents (Irifune et al. 1994).

In summary, low-degree melting of dry pelitic rock at pressures below $3.0 \mathrm{GPa}$ is dominated by feldspar and quartz, as is also the case for dry melting of granitic rock under crustal conditions (e.g., Stern and Wyllie 1973). With increasing pressure above $3.0 \mathrm{GPa}$, jadeitic clinopyroxene stability increases and feldspar approaches the potassic end-member composition. Low-degree melts are dacitic with very high $\mathrm{K}_{2} \mathrm{O} / \mathrm{Na}_{2} \mathrm{O}$ contents. At higher degrees of melting, clinopyroxene, followed by garnet and kyanite, are dissolved, leaving quartz/coesite as the sole liquidus phase across a large temperature interval. Phase assemblages at pressures above $13 \mathrm{GPa}$ are dominated by stishovite, K-hollandite and garnet, and melts tend to Na-rich andesitic compositions.

\section{Implications for ocean island magmatism}

The highly distinctive petrology and geochemistry of sedimentary rocks relative to mantle peridotite means that mantle-derived magmas should have distinctive chemical signatures if their source contains even a tiny fraction of sedimentary components. The vast majority of oceanic magmas (MORB and OIB) do not show clear evidence that sediments constitute part of their mantle source, which indicates that sedimentary components are not homogenously distributed in the upper mantle. Instead, we expect that previously subducted crustal rocks (mafic eclogites and metasediments) may be concentrated together with old subducted lithosphere and/or asthenospheric peridotite into heterogeneous mantle domains. Such zones may represent a mantle upwelling or plume with relative buoyancy attributable to compositional and/or thermal heterogeneity.

Melting of heterogeneous mantle is likely to be extremely complicated (for example, see Spandler et al. 2008), so here we focus only on aspects of melting of sedimentary components. Our results indicate that anhydrous metasedimentary rocks in the mantle will begin melting at temperatures of $50-150^{\circ} \mathrm{C}$ lower than melting of MORB-type eclogites (Yasuda et al. 1994; Pertermann and Hirschmann 2003; Spandler et al. 2008) and around $300-400^{\circ} \mathrm{C}$ lower than melting of dry peridotite (Hirschmann 2000). The lower solidus temperature of metasediments is consistent with lowering of the solidus due to high alkali contents (Kogiso and Hirschmann 2006) or due to subsolidus stability of low melting point phases such as apatite, rutile and feldspar (Spandler et al. 2008). For typical mantle adiabats (McKenzie and Bickle 1988; Green et al. 2001) metasediments in upwelling mantle will begin to melt at 200$350 \mathrm{~km}$ depth, which is $\sim 50-200 \mathrm{~km}$ deeper than mafic eclogites. The initial melts produced will be ultrapotassic and silica-rich, and hence, will not be in equilibrium with the surrounding peridotite. These melts are expected to quickly react with the peridotite to form metasomatic pyroxenite or refertilised peridotite (see Yaxley and Green 1998). This reaction process is an important means of transferring isotopic and trace-element signatures of the former sediment to significant volumes of mantle peridotite. After melt extraction, the sediment residues are likely 
to approach eclogitic compositions, but will retain high $\mathrm{SiO}_{2}$ contents. With further upwelling, these residues will continue to melt and the silica-rich melts continue to react with the enclosing peridotite. However, the liquidus temperatures are close to, or in excess of, the peridotite solidus (Hirschmann 2000), so complete melting of dry pelitic sediment may never be realised in the mantle. At around 3-4 GPa or less, melting of the metasomatised olivine pyroxenites and peridotites will occur (Spandler et al. 2008). Importantly, melting of the metasomatic rocks at these relatively shallow depths probably does not significantly fractionate $\mathrm{Na}$ and $\mathrm{K}$, so the melts produced are likely to inherit the $\mathrm{K}-\mathrm{Na}$ systematics, as well as the isotopic and trace-element enrichments of the initial metasomatism and thus of deep sediment melts. These newly produced melts are then expected to rise through the lithosphere to form oceanic magma suites (e.g., Sobolev et al. 2007). This scenario should by no means be taken as an accurate model for melt generation in the mantle. It does not account for the potential complexities of magma mixing, melt-rock reaction and magma transport, but it may provide some first order constraints on the role of melting of sediments for ocean island magmatism.

A minority of oceanic magmas do have distinctive geochemical and isotopic compositions that indicate that they were derived from a mantle source containing ancient sediments. These magmas include EM1- and EM2-type OIBs (e.g., Eisele et al. 2002; Hofmann 2003; Jackson et al. 2007; Class and le Roex 2008; Jackson and Dasgupta 2008). Recent geochemical modelling has been used to suggest that sediments comprise up to $6 \%$ of the source of these magmas, but in all cases these figures are calculated assuming bulk sediment addition (e.g., Eisele et al. 2002; Jackson et al. 2007; Chauvel et al. 2008). An important result of this study is the recognition of the large melting interval for anhydrous sediments in the mantle (Fig. 2). As described above, sediments will undergo melting over a huge depth range during mantle upwelling, and it is most likely that discrete melt batches are episodically extracted from these materials. Therefore, we argue that modelling of oceanic magmas using a bulk sediment component is not appropriate, and consideration of melting and melt extraction processes need to be taken into account.

Low-degree melts of sediment are expected to be the highly enriched in incompatible trace elements (e.g., K, $\mathrm{Rb}, \mathrm{Sr}, \mathrm{U}, \mathrm{Th}, \mathrm{Pb}, \mathrm{LREE}$ ), so sourcing of only very small proportions $(<1 \%)$ of these melts may account for most of the so-called 'sedimentary' chemical signature of erupted EM1 and EM2 lavas. Such small volumes of sedimentary melts would not significantly influence the major element and stable isotope composition of these magmas, as proposed by Class and le Roex (2008). However, Jackson and Dasgupta (2008) did recognise that EM2- and, to a lesser extent, EM1-type basalts are enriched in $\mathrm{K}_{2} \mathrm{O}$ relative to other hotspot basalts, a feature they attributed to a metasedimentary component in their source regions. Based on our results, we would argue that high $\mathrm{K}_{2} \mathrm{O} / \mathrm{Na}_{2} \mathrm{O}$ should be a diagnostic feature of low-degree sediment melts formed in the mantle, so this signature could be preserved in EM1 and EM2 lavas. To test this hypothesis, we have plotted the $\mathrm{K}_{2} \mathrm{O} / \mathrm{Na}_{2} \mathrm{O}$ versus $\mathrm{Sr}$ and $\mathrm{Hf}$ isotopic composition of primitive mafic lavas from various OIB suites (see Fig. 8). We took care to exclude samples that were affected by post-magmatic alteration or weathering. The $\mathrm{Sr}$ and $\mathrm{Hf}$ isotopic ratios of these magmas serve as a proxy for the amount of sediment in the magma source, with higher ${ }^{87} \mathrm{Sr} /{ }^{86} \mathrm{Sr}$ and lower ${ }^{176} \mathrm{Hf} /{ }^{177} \mathrm{Hf}$ ratios corresponding to larger apparent sediment contributions. However, we stress that this is a generalisation, as isotopic systematics of source materials will vary according to the initial isotopic composition and age. We also do not attempt any detailed geochemical modelling of these data, as this would require rigorous evaluation of the source characteristics, melting behaviour and effects of crystal fractionation and alteration for each individual magma suite, work that is beyond the scope of this paper. Here, we highlight that there is, in general, a correlation between the $\mathrm{K}_{2} \mathrm{O} / \mathrm{Na}_{2} \mathrm{O}$ and $\mathrm{Sr}$ and $\mathrm{Hf}$ isotopic composition of a range of EM1 and EM2 magma suites (Fig. 8). This correlation not only supports the involvement of sedimentary components in EM1 and EM2 magma sources but is most easily reconciled if lowdegree sediment melts, rather than bulk sediment, are the dominant sedimentary component in these magmas. For comparative purposes, we also include data for magmas from Hawaii, which do not follow the same trend as the EM1 and EM2 magmas. This feature is consistent with the general consensus that recycled mafic oceanic crust, rather than sediments, is the dominant crustal component contributing to the production of Hawaiian magmas (Hofmann and Jochum 1996; Sobolev et al. 2005; Herzberg 2006).

Implications for mantle seismic structure

Sedimentary rocks subducted in the mantle are dominated by silica-rich lithologies, such as chert, siliceous ooze, sandstone and siltstone (Plank and Langmuir 1998). Our results indicate that free silica (quartz/coesite/stishovite) will be not only a major constituent but also the liquidus phase (Fig. 2) of these rocks in the upper mantle. Therefore, siliceous residual bodies could be formed due to melting and melt extraction from metasediments in heterogeneous mantle domains. Although pure silica will not melt out under any reasonable mantle geotherm (Swamy et al. 1994), it is not in equilibrium with olivine-bearing mantle peridotite and, hence, will undergo diffusive reequilibration to form orthopyroxene. Knowledge of 

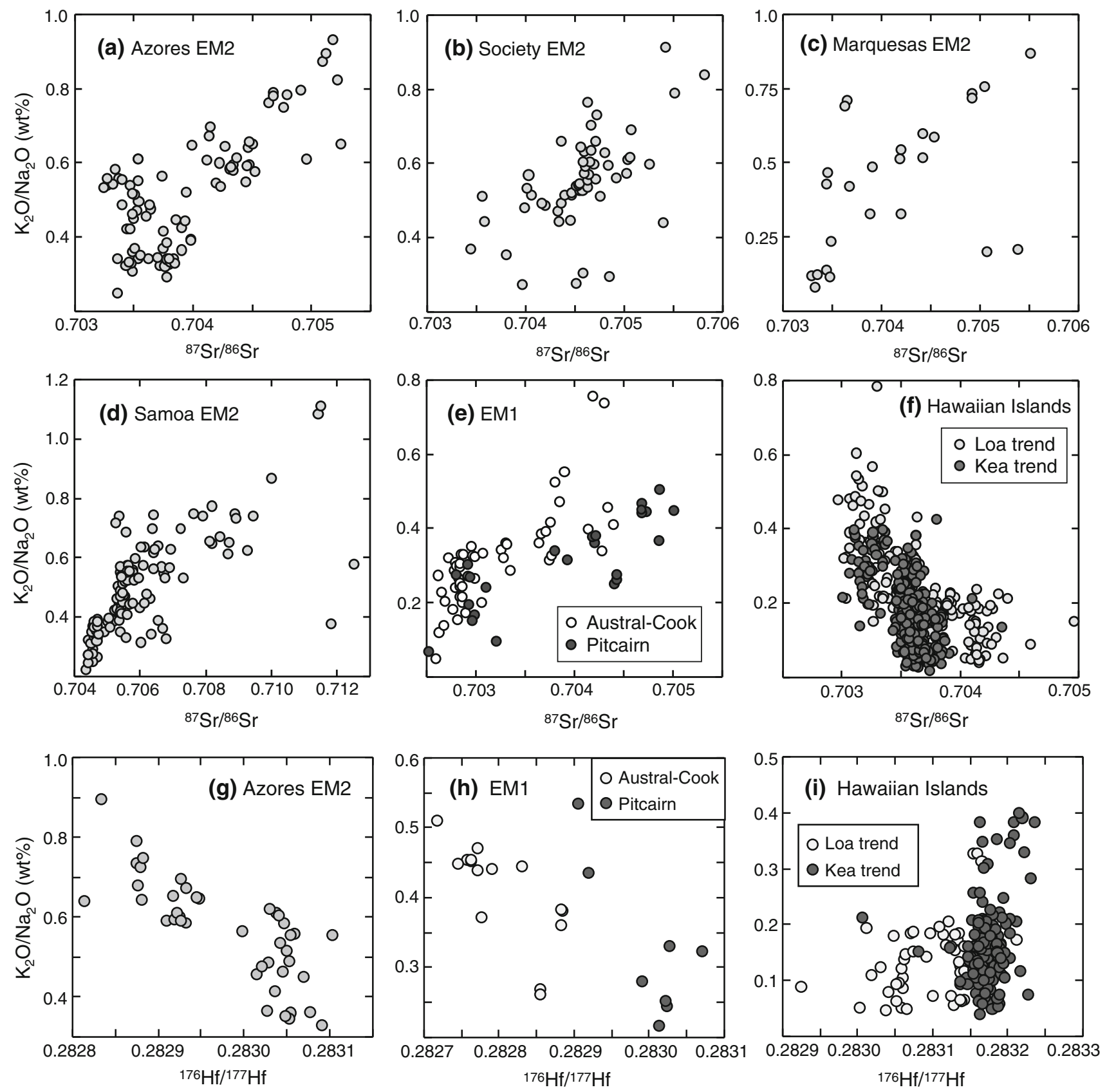

Fig. $8 \quad \mathrm{~K}_{2} \mathrm{O} / \mathrm{Na}_{2} \mathrm{O}(\mathrm{wt} \%$ ) versus $\mathrm{Sr}$ and $\mathrm{Hf}$ isotopic composition of various ocean island magma suites. All plotted data are primitive $(\mathrm{MgO}>6 \mathrm{wt} \%)$ mafic lavas, which have been filtered for alteration by rejecting analyses that have high volatile or loss-on-ignition contents or analyses where alteration was documented. Magma suites that have been demonstrated to be affected by shallow level crustal contamination (e.g., Kerguelen, Canaries) have not been plotted. Note

diffusion rates under these conditions is incomplete, but calculations by Kogiso et al. (2004) suggest that it may take over 2 billion years to equilibrate heterogeneities greater than several metres in size. The dimensions and vigour of mechanical mixing of heterogeneities with mantle peridotite are currently not well constrained, but it the general correlation of $\mathrm{K}_{2} \mathrm{O} / \mathrm{Na}_{2} \mathrm{O}$ and $\mathrm{Sr}$ and $\mathrm{Hf}$ isotope composition for the EM1 and EM2 magmas, which is consistent with the involvement of sedimentary components in the source regions of these magmas. In contrast, magmas from Hawaii do not follow this trend. Data sourced from Jackson et al. (2007) and the GEOROC database (http://georoc.mpch-mainz.gwdg.de/georoc/)

is clear that some heterogeneity is preserved in order to explain the isotopic and geochemical variation of OIB magmas (van Keken et al. 2002). Therefore, it is conceivable that the rather peculiar circumstance of bodies of free silica coexisting with peridotite and eclogite may be realised in heterogeneous mantle domains. 
The presence of free silica in mantle domains may be important for interpretations of mantle seismic signatures. Rossi et al. (2006) appealed to the presence of significant quartz in the deep mantle wedge beneath central Alaska, in order to explain usually low $V_{\mathrm{p}} / V_{\mathrm{s}}$ values. The high-pressure silica polymorphs coesite and stishovite have very different physical properties, which led Williams and Revenaugh (2005) to suggest that the sporadically observed $300-\mathrm{km}$ (or ' $\mathrm{X}$ ') seismic discontinuity in the mantle is caused by the coesite to stishovite transition of free silica in mafic eclogite. The depth of the discontinuity correlates well with the expected phase transition, and the impedance contrast which is needed to produce the observed discontinuity only requires a small fraction of free silica in the mantle region. Mafic eclogite should be significantly more voluminous than metasedimentary material in the mantle, but the sedimentary material is likely to be significantly richer in silica. Considering the composition, volume and high-pressure petrology of subducted oceanic crust and sediments (e.g., Plank and Langmuir 1998; Klein 2003; Pertermann and Hirschmann 2003; Spandler et al. 2008), we estimate that subducted sediments could account for a similar amount of free silica in the mantle as mafic eclogite. Moreover, the neutral or near-neutral buoyancy of sedimentary compositions in the mantle at depths close to the coesite-stishovite transition (Irifune et al. 1994; Wu et al. 2009) would favour prolonged storage of subducted sediments at these depths in the mantle. In this case, the $300 \mathrm{~km}$ discontinuity may not just be caused by eclogite in the mantle (Williams and Revenaugh 2005; Bagley and Revenaugh 2008), but may also identify locations of mantle domains containing ancient recycled sediments (possibly together with eclogite). The recognition of the $300 \mathrm{~km}$ discontinuity in heterogeneous mantle zones associated with island arcs (e.g., Tonga; Zheng et al. 2007; Northern Pacific; Bagley and Revenaugh 2008) and beneath ocean-island volcanoes (e.g., Hawaii; Schmerr and Garnero 2006) lend credence to this hypothesis.

\section{Conclusion}

Our experimental results indicate that sedimentary compositions in the upper mantle have complex melting behaviours and phase relations that are quite distinct from other mantle rock-types. Specifically, we highlight the important roles of feldspar and clinopyroxene on relatively low-degree melting and the role of free silica as a residual phase at high temperatures and high degrees of melting. Bodies of previously subducted sediment included into heterogeneous mantle domains are likely to undergo melting at depths greater than $200 \mathrm{~km}$ to produce distinctive alkaline, silicic melts. Such melts should react with surrounding mantle materials, but ultimately may be critical to the formation of distinctive and variable isotopic and trace-element signatures of some intraplate magma suites. Free silica may occur in relics from sedimentary protoliths in the mantle, even under conditions of extensive melting, and this material may contribute to some anomalous seismic discontinuities that have been observed in the mantle.

Acknowledgments We thank Marc Hirschmann and an anonymous reviewer for thoughtful reviews. Marco Herwegh, Frank Brink and Kevin Blake provided assistance to the SEM and electron microprobe analyses. This work was supported by the Australian Research Council (DP0558189).

\section{References}

Abers GA, van Keken PE, Kneller EA, Ferris A, Stachnik JC (2006) The thermal structure of subduction zones constrained by seismic imaging: implications for slab dehydration and wedge flow. Earth Planet Sci Lett 241:387-397

Anderson DL (2006) Speculations on the nature and cause of mantle heterogeneity. Tectonophysics 416:7-22

Andres M, Blichert-Toft J, Schilling J-G (2002) Hafnium isotopes in basalts from the southern Mid-Atlantic Ridge from $40^{\circ} \mathrm{S}$ to $44^{\circ} \mathrm{S}$ : discovery and Shona plume-ridge interactions and the role of recycled sediments. Geochem Geophys Geosyst 3. doi: 2002GC000324

Bagley B, Revenaugh J (2008) Upper mantle seismic shear discontinuities of the Pacific. J Geophys Res 113. doi:10.1029/ 2008JB005692

Bebout GE, Barton MD (2002) Tectonic and metasomatic mixing in a high-T, subduction-zone melange-insights into the geochemical evolution of the slab-mantle interface. Chem Geol 187: 79-106

Becker H, Altherr R (1992) Evidence from ultra-high-pressure marbles for recycling of sediments into the mantle. Nature 358:745-748

Bose K, Ganguly J (1995) Quartz-coesite transition revisited: Reversed experimental determination at $500-1200^{\circ} \mathrm{C}$ and retrieved thermochemical properties. Am Mineral 80:231-238

Brenker FE, Vincze L, Vekemans B et al (2005) Detection of a Ca-rich lithology in the Earth's deep (>300 km) convecting mantle. Earth Planet Sci Lett 236:579-587

Busigny V, Cartigny P, Philippot P, Ader M, Javoy M (2003) Massive recycling of nitrogen and other fluid mobile elements $(\mathrm{K}, \mathrm{Rb}, \mathrm{Cs}$, $\mathrm{H})$ in a cold slab environment: evidence from $\mathrm{HP}$ to UHP oceanic metasediments of the Schists Lustrés nappe (Western Alps, Europe). Earth Planet Sci Lett 215:27-42

Chauvel C, Lewin E, Carpentier M, Arndt NT, Marini J-C (2008) Role of recycled oceanic basalt and sediment in generating the Hf-Nd mantle array. Nat Geosci 1:64-67

Chauvel C, Marini J-C, Plank T, Ludden JN (2009) Hf-Nd input flux in the Izu-Mariana subduction zone and recycling of subducted material in the mantle. Geochem Geophys Geosyst 10. doi: 10.1029/2008GC002101

Chopin C (2003) Ultrahigh-pressure metamorphism: tracing continental crust into the mantle. Earth Planet Sci Lett 212:1-14

Class C, le Roex AP (2008) Ce anomalies in Gough Island lavastrace element characteristics of a recycled sediment component. Earth Planet Sci Lett 265:475-486 
Daniels LRM, Gurney JJ, Harte B (1996) A crustal mineral in a mantle diamond. Nature 379:153-156

Dobrzhinetskaya LF, Green HW (2007) Experimental studies of mineralogical assemblages of metasedimentary rocks at Earth's mantle transition zone conditions. J Metamorph Geol 25:83-96

Domanik KJ, Holloway JR (1996) The stability and composition of phengitic muscovite and associated phases from 5.5 to $11 \mathrm{GPa}$ : implications for deeply subducted sediments. Geochim Cosmochim Acta 60:4133-4150

Ducea MN (2002) Constraints on the bulk composition and root foundering rates of continental arcs: a California arc perspective. J Geophys Res 107. doi:10.1029/2001JB000643

Eiler JM, Farley KA, Valley JW, Hauri E, Craig H, Hart SR, Stolper EM (1997) Oxygen isotope variations in ocean island basalt phenocrysts. Geochim Cosmochim Acta 61:2281-2293

Eisele J, Sharma M, Galer SJG, Blichert-Toft J, Devey CW, Hofmann AW (2002) The role of sediment recycling in EM-1 inferred from $\mathrm{Os}, \mathrm{Pb}, \mathrm{Hf}, \mathrm{Nd}$, Sr isotope and trace element systematics of the Pitcairn hotspot. Earth Planet Sci Lett 196:197-212

Eldridge CS, Compston W, Williams IS, Harris JW, Bristow JW (1991) Isotope evidence for the involvement of recycled sediments in diamond formation. Nature 353:649-653

Ellis DJ, Green DH (1979) An experimental study of the effect of Ca upon garnet-clinopyroxene $\mathrm{Fe}-\mathrm{Mg}$ exchange equilibria. Contrib Mineral Petrol 71:13-22

Green DH, Lambert IB (1965) Experimental crystallization of anhydrous granite at high pressures and temperatures. J Geophys Res 70:5259-5268

Green DH, Falloon TJ, Eggins SM, Yaxley GM (2001) Primary magmas and mantle temperatures. Euro J Mineral 13:437-451

Hermann J, Green DH (2001) Experimental constraints on high pressure melting in subducted crust. Earth Planet Sci Lett 188:49-168

Hermann J, Rubatto D (2009) Accessory phase control on the trace element signature of sediment melts in subduction zones. Chem Geol 265:512-526

Hermann J, Spandler C (2008) Sediment melts at sub-arc depths: an experimental study. J Petrol 49:717-740

Hermann J, HStC O'Neill, Berry AJ (2005) Titanium solubility in olivine in the system $\mathrm{TiO}_{2}-\mathrm{MgO}-\mathrm{SiO}_{2}$ : no evidence for an ultradeep origin of Ti-bearing olivine. Contrib Mineral Petrol 148:746-760

Hermann J, Spandler CJ, Hack A, Korsakov A (2006) Aqueous fluids and hydrous melts in high-pressure and ultra-high pressure rocks: implications for element transfer in subduction zones. Lithos 92:399-417

Herzberg C (2006) Petrology and thermal structure of the Hawaiian plume from Mauna Kea volcano. Nature 444:605-609

Hirschmann MM (2000) Mantle solidus: experimental constraints and the effect of peridotite composition. Geochem Geophys Geosyst 1. doi:2000GC000070

Hirschmann MM, Kogiso T, Baker MB, Stolper EM (2003) Alkalic magmas generated by partial melting of garnet pyroxenite. Geology 31:481-484

Hofmann AW (2003) Sampling mantle heterogeneity through oceanic basalts: isotopes and trace elements. In: Carlson RW, Holland HD, Turekian KK (eds) Treatise on geochemistry. 2. The mantle and core. Elsevier, Amsterdam, pp 61-101

Hofmann AW, Jochum KP (1996) Source characteristics derived from very incompatible trace elements in Mauna Loa and Mauna Kea basalts, Hawaii Scientific Drilling Project. J Geophys Res 101:11831-11839

Holland TJB (1980) The reaction albite $=$ jadeite + quartz determined experimentally in the range $600-1200^{\circ} \mathrm{C}$. Am Mineral 65:129-134
Huang S, Frey FA (2005) Recycled oceanic crust in the Hawaiian Plume: evidence from temporal geochemical variations within the Koolau Shield. Contrib Mineral Petrol 149:556-575

Irifune T, Ringwood AE, Hibberson WO (1994) Subduction of continental crust and terrigenous and pelagic sediments: an experimental study. Earth Planet Sci Lett 126:351-368

Jackson MG, Dasgupta R (2008) Compositions of HIMU, EM1, and EM2 from global trends between radiogenic isotopes and major elements in ocean island basalts. Earth Planet Sci Lett 276: $175-186$

Jackson MG, Hart SR, Koppers AAP, Staudigel H, Konters J, Blusztajn J, Kurz M, Russel JA (2007) The return of subducted continental crust in Samoan lavas. Nature 448:684-687

Kelemen P, Hacker B, Austin N (2007) How does recycling of sediment components in arc magmatism really work? AGU Fall meeting Abstract no. V51G-04

Kerrick DM, Connolly JAD (2001) Metamorphic devolatilization of subducted marine sediments and the transport of volatiles into the Earth's mantle. Nature 411:293-296

Kessel R, Schmidt MW, Ulmer P, Pettke T (2005) Trace element signature of subduction-zone fluids, melts and supercritical liquids at $120-180 \mathrm{~km}$ depth. Nature 437:724-727

Kincaid C, Griffiths RW (2004) Variability in flow and temperature within mantle subduction zones. Geochem Geophys Geosyst 5:Q06002

Klein EM (2003) Geochemistry of the igneous oceanic crust. In: Rudnick RL, Holland HD, Turekian KK (eds) Treatise on geochemistry. 3. The crust. Elsevier, Amsterdam, pp 433-463

Klimm K, Blundy JD, Green TH (2008) Trace element partitioning and accessory phase saturation during $\mathrm{H}_{2} \mathrm{O}$-saturated melting of basalt with implications for subduction zone chemical fluxes. J Petrol 49:523-553

Kogiso T, Hirschmann MM (2006) Partial melting experiments of bimineralic eclogite and the role of recycled mafic oceanic crust in the genesis of ocean island basalts. Earth Planet Sci Lett 249:188-199

Kogiso T, Hirschmann MM, Reiners PW (2004) Length scales of mantle heterogeneities and their relationship to ocean island basalt geochemistry. Geochim Cosmochim Acta 68:345-360

Konzett J, Frost DJ, Proyer A, Ulmer P (2008) The Ca-Eskola component in eclogitic clinopyroxene as a function of pressure, temperature and bulk composition: an experimental study to 15 GPa with possible implications for the formation of oriented $\mathrm{SiO}_{2}$ inclusions in omphacite. Contrib Mineral Petrol 155:215-228

Liu L, Zhang J, Green HW II, Jin Z, Bozhilov KN (2007) Evidence of former stishovite in metamorphosed sediments, implying subduction to $>350 \mathrm{~km}$. Earth Planet Sci Lett 263:180-191

McKenzie D, Bickle MJ (1988) The volume and composition of melt generated by extension of the lithosphere. J Petrol 29:625-679

Nichols GT, Wyllie PJ, Stern CR (1994) Subduction zone-melting of pelagic sediments constrained by melting experiments. Nature 371:785-788

Nielsen SG, Rehkamper M, Norman MD, Halliday AN, Harrison D (2006) Thallium isotope evidence for ferromanganese sediments in the mantle source of Hawaiian basalts. Nature 439:314-317

Ono S (1998) Stability limits of hydrous minerals in sediments and mid-ocean ridge basalt compositions: implications for water transport in subduction zones. J Geophys Res 103. doi:10.1029/ 98JB01351

Pertermann M, Hirschmann MM (2003) Anhydrous partial melting experiments on MORB-like eclogite: phase relations, phase compositions and mineral-melt partitioning of major elements at 2-3 GPa. J Petrol 44:2173-2201

Plank T, Langmuir CH (1998) The chemical composition of subducting sediment and its consequences for the crust and mantle. Chem Geol 145:325-394 
Rapp RP, Irifune T, Shimizu N, Nishiyama N, Norman MD, Inoue T (2008) Subduction recycling of continental sediments and the origin of geochemically enriched reservoirs in the deep mantle. Earth Planet Sci Lett 271:14-23

Rehkämper M, Hofmann AW (1997) Recycled ocean crust and sediment in Indian Ocean MORB. Earth Planet Sci Lett 147: 93-106

Rossi G, Abers GA, Rondenay S, Christensen DH (2006) Unusual mantle Poisson's ratio, subduction, and crustal structure in central Alaska. J Geophys Res 111. doi:10.1029/2005JB003956

Rudnick RL, Gao S (2003) Composition of the continental crust. In: Rudnick RL (ed) Treatise on geochemistry. 3. The crust. Elsevier, Amsterdam, pp 1-64

Schertl H-P, Schreyer W (2008) Geochemistry of coesite-bearing "pyrope quartzite" and related rocks from the Dora Maira Massif, Western Alps. Euro J Mineral 20:791-809

Schmerr N, Garnero E (2006) Investigation of upper mantle discontinuity structure beneath the central Pacific using SS precursors. J Geophys Res 111. doi:10.1029/2005JB004197

Schmidt MW, Poli S (2003) Generation of mobile components during subduction of oceanic crust. In: Rudnick RL (ed) Treatise on geochemistry. 3. The crust. Elsevier, Amsterdam, pp 567-591

Schmidt MW, Vielzeuf D, Auzanneau E (2004) Melting and dissolution of subducting crust at high pressures: the key role of white mica. Earth Planet Sci Lett 228:65-84

Shatsky VS, Sobolev NV (2003) The Kokchetav massif of Kazakhstan. In: Carswell DA, Compagnoni R (eds) Ultrahigh pressure metamorphism, vol 5. European Mineralogical Union Notes, pp 75-103

Sobolev AV, Hofmann AW, Sobolev SV, Nikogosian IK (2005) An olivine-free mantle source of Hawaiian shield basalts. Nature 434:590-597

Sobolev AV, Hofmann AW, Kuzmin DV et al (2007) The amount of recycled crust in the sources of mantle-derived melts. Science 316:412-417

Spandler CJ, Hermann J, Arculus RJ, Mavrogenes JA (2003) Redistribution of trace elements during prograde metamorphism from lawsonite blueschist to eclogite facies; implications for deep subduction-zone processes. Contrib Mineral Petrol 146:205-222

Spandler C, Mavrogenes J, Hermann J (2007) Experimental constraints on element mobility from subducted sediments using high-P synthetic fluid/melt inclusions. Chem Geol 239:228-249

Spandler C, Yaxley G, Green DH, Rosenthal A (2008) Phase relations and melting of anhydrous K-bearing eclogite from 1200 to $1600^{\circ} \mathrm{C}$ and 3 to $5 \mathrm{GPa}$. J Petrol 49:771-795

Stern CR, Wyllie PJ (1973) Water-saturated and undersaturated melting relations of a granite to 35 kilobars. Earth Planet Sci Lett 18:163-167
Stern CR, Huang WL, Wyllie PJ (1975) Basalt-andesite-rhyolite$\mathrm{H}_{2} \mathrm{O}$-crystallization intervals with excess $\mathrm{H}_{2} \mathrm{O}$ and $\mathrm{H}_{2} \mathrm{O}$ undersaturated liquidus surfaces to 35 kilobars, with implications for magma genesis. Earth Planet Sci Lett 28:189-196

Stracke A, Bizimis M, Salters VJM (2003) Recycling oceanic crust: quantitative constraints. Geochem Geophys Geosyst 4. doi: 10.1029/2001GC000223

Swamy V, Saxena SK, Sundman B, Zhang J (1994) A thermodynamic assessment of silica phase diagram. J Geophys Res 99:1178711794

Tatsumi Y (2005) The subduction factory: how it operates in the evolving Earth. GSA Today 15:4-10

Thomsen TB, Schmidt MW (2008) Melting of carbonated pelites at 2.5-5.0 GPa, silicate-carbonatite liquid immiscibility, and potassium-carbon metasomatism of the mantle. Earth Planet Sci Lett 267:17-31

van Keken PE, Hauri EH, Ballentine CJ (2002) Mantle mixing: the generation, preservation, and destruction of chemical heterogeneity. Ann Rev Earth Planet Sci 30:493-525

Weaver BL (1991) The origin of ocean island basalt end-member compositions: trace element and isotopic constraints. Earth Planet Sci Lett 104:381-397

Williams Q, Revenaugh J (2005) Ancient subduction, mantle eclogite, and the $300 \mathrm{~km}$ seismic discontinuity. Geology 33:1-4

Wu Y, Fei Y, Jin Z, Liu X (2009) The fate of subducted upper continental crust: an experimental study. Earth Planet Sci Lett 282:275-284

Yasuda A, Fujii T, Kurita K (1994) Melting phase relations of an anhydrous mid-ocean ridge basalt from 3 to $20 \mathrm{GPa}$ : Implications for the behaviour of subducted oceanic crust in the mantle. J Geophys Res 99:9401-9414

Yaxley GM (2000) Experimental study of the phase and melting relations of homogeneous basalt plus peridotite mixtures and implications for the petrogenesis of flood basalts. Contrib Mineral Petrol 139:326-338

Yaxley GM, Green DH (1998) Reactions between eclogite and peridotite: Mantle refertilisation by subduction of oceanic crust. Schweiz Mineral Petrogr Mitt 78:243-255

Yaxley GM, Sobolev AV (2007) High-pressure partial melting of gabbro and its role in the Hawaiian magma source. Contrib Mineral Petrol 154:371-383

Zack T, John T (2007) An evaluation of reactive fluid flow and trace element mobility in subducting slabs. Chem Geol 239:199-216

Zheng Y, Lay T, Flanagan MP, Williams Q (2007) Pervasive seismic wave reflectivity and metasomatism of the Tonga mantle wedge. Science 316:855-859 